\title{
4-H SWINE PROJECT MANUAL BOOK 1
}

Florida Cooperative Extension Service Institute of Food and Agricultural Sciences University of Florida, Gainesville

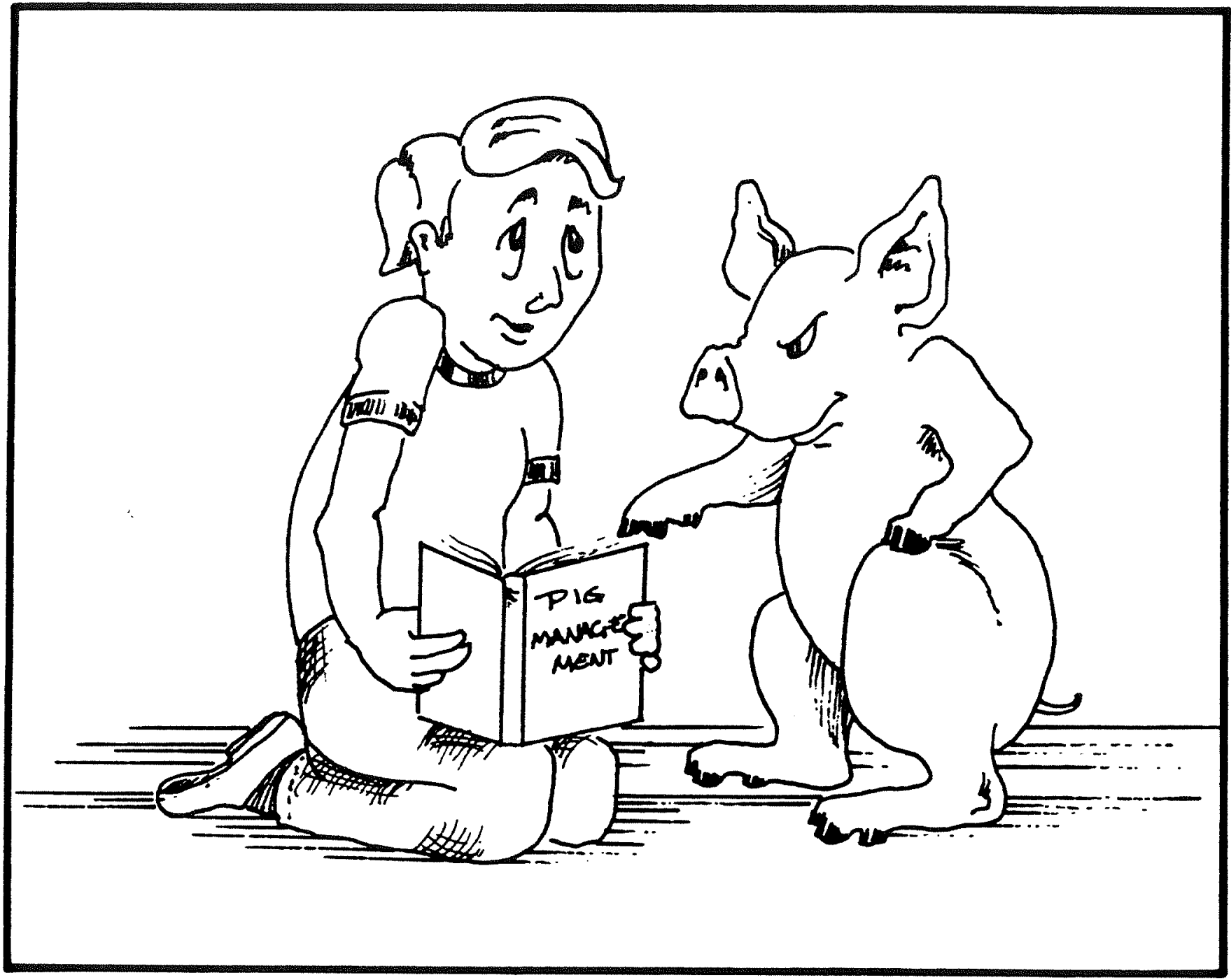

Name Date of Birth

Address

Grade in School

Years in 4-H Name of School

Name of local Club

Parent or Guardian

Local Leader

County Extension Agent County 


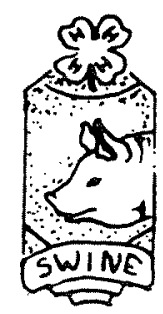

\section{INTRODUCTION}

This manual is written for you. Use it as a guide for your $4-\mathrm{H}$ pig project. Instructions tell how to choose your pig and prepare a home for it. You will learn how to care for it, and there is a chapter on how to groom and show your pig. Remember this project is yours. Do as much as you can, but be willing to call on others for help.

\section{TABLE OF CONTENTS}

Introduction

History of the Pig

A Note to Parents and Leaders

The Field Trip

Objectives 10

Getting to Know Breeds _ 11

Getting to Know Parts of a Pig__ 13

Tommy Starts a Project _ـ 16

Preparing for Your Project __ 18

Tommy Buys his Pig — 19

Selecting Your Pig 24

Tommy's Pig Settles In 25

Care of Your Pig _ 28

The County Show 30

Showing Your Project Pig __ 32

Tommy Pays a Visit _ 33

Answers to Most Often Asked Questions __ 38

Talking Hogs __ 39

References __ 39 


\section{HISTORY OF THE PIG}

The pig has been on the North American continent (what is now the United States) for over 440 years, having been brought to the west coast of the Florida peninsula in what is now Port Charlotte, Florida by Hernando DeSoto on May 25, 1539. Apparently these animals were a hardy lot, rangy in type, and approximately 300 head began the march with the soldiers up through the peninsula all the way to the Mississippi River. DeSoto soon learned one of his best trade items with the Indians was the pig. Thus the pig was on this continent almost a century before the Pilgrims landed at Plymouth Rock.

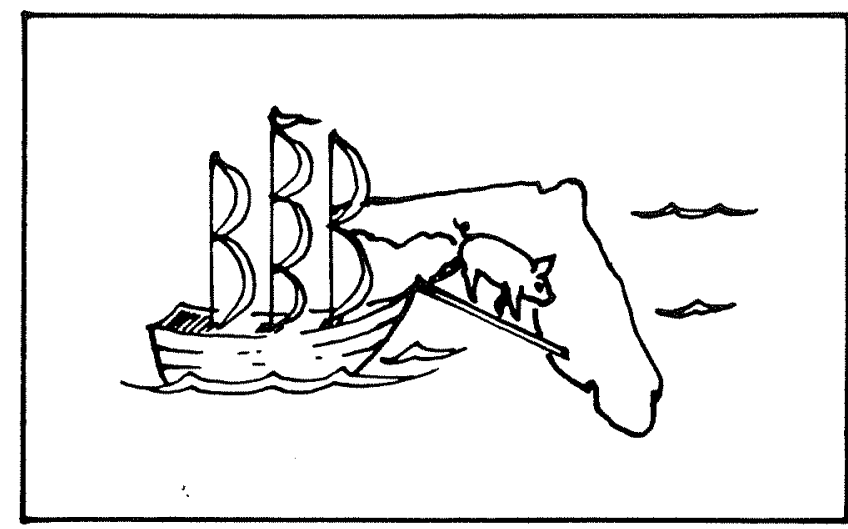

Since that time, with the addition of other imported breeds, the swine industry has grown to an estimated 67 million head on farms as of December 1,1979 . China is the No. 1 producer of hogs in the world, followed by the United States and Brazil.

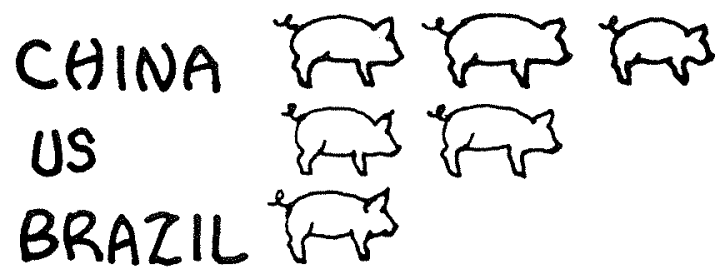

Most of the hogs produced in the United States are in the midwestern states, with lowa being No. 1 with over 16 million hogs. Florida ranks 24 th in hog numbers with 425,000 . There are approximately 8200 farms with hogs in our state with animals valued at 23 million dollars.
Facilities to produce these animals are valued at approximately 50 million dollars.

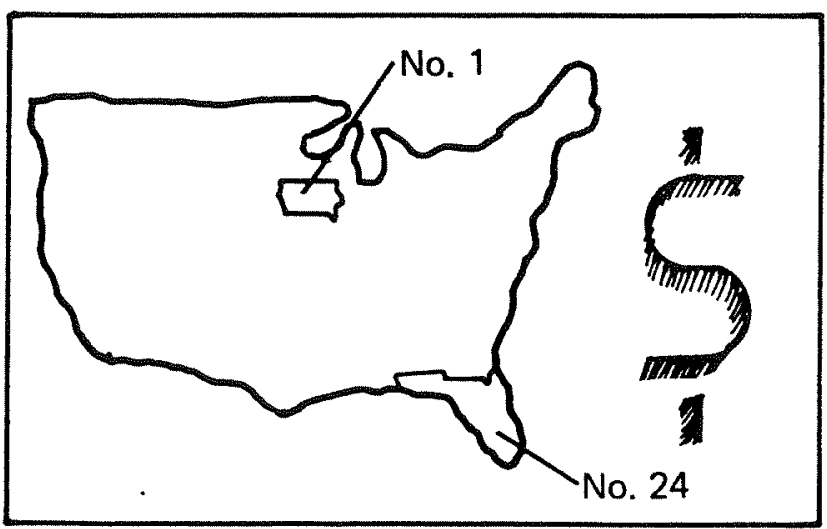

Pork is nutritious! A serving of 3.5 ounces supplies approximately 44 per cent of our daily requirement of protein and many of the important vitamins and minerals.

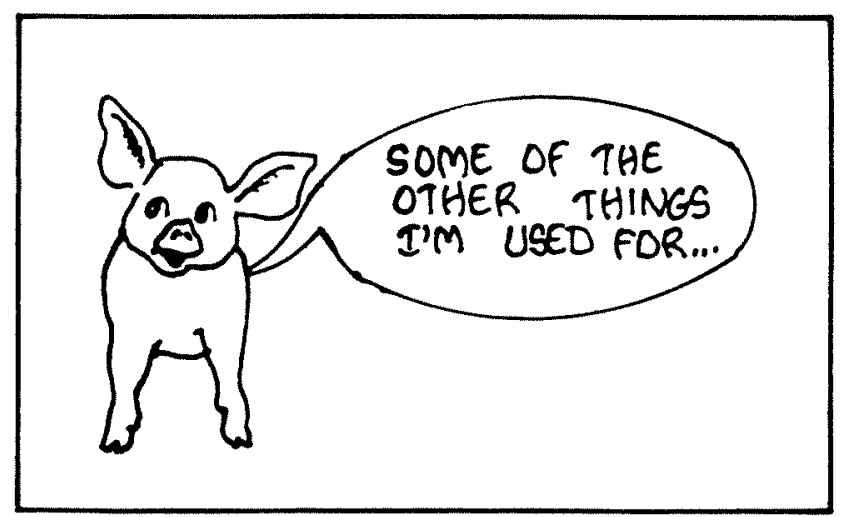

The pig furnishes many other things besides good, edible pork chops, ham, bacon, sausage and spareribs. For instance, the pig stomach is a prime source of the enzyme "pepsin" used in chewing gum; pig skin is a major source of quality gluten used in desserts, ice cream mixes, etc. In medicine there are over 50 uses of the different pork by-products, such as heart valves used for transplant in humans and drugs used to treat asthma, whooping cough and diabetes. Hogs are used as subjects of experiments on alcoholism at the University of Missouri. The hair is used for bristles for brushes. Thus, the old saying is true, "everything is used from the pig but the squeal," and now that has even been recorded for movies and television.

The hog is truly an outstanding animal that is one of the most intelligent animals in America, ranking above the cat, dog, cow and horse and just below the monkey on the intelligence scale. 


\section{A Note To Parents and Leaders}

You are the most important influence in a 4-H'ers life. As such you can play very important roles in guiding them through their project, making it a pleasant and rewarding experience. This material provides opportunities to learn and develop with the help of the County Extension 4-H Coordinator and you. Following are some things you can do to help the $4-\mathrm{H}^{\prime}$ er get the most out of this project:

1. Become familiar with material in this publication.

2. Using the information and talking with the 4-H coordinator, help 4- $\mathrm{H}^{\prime}$ er choose goals that can be fulfilled.

3. Assist in deciding what tools, equipment and supplies will be needed, and help 4-H'er put the project together.

4. Help 4-H'er to understand and learn the tasks necessary to carry out the planned project. DON'T DO ALL OF THE WORK YOURSELF!

5. Review 4-H'ers records occasionally to make sure the records are up to date. This is a very important part of the project and should not be neglected.

6. Discuss the progress of the project and help 4-H'er to recognize the difference between a good job and a bad one.

7. Help 4-H'er to understand where project improvements are needed, and remember - your compliments for a job well done are important.

8. Help 4-H'er to know and evaluate the project and effort expended on the basis of goals and objectives set.

9. Assist $4-\mathrm{H}^{\prime} \mathrm{er}$ with establishing long range goals and selecting projects to meet this challenge.

10. AVOID COMPARING 4-H'ER WITH OTHERS. 


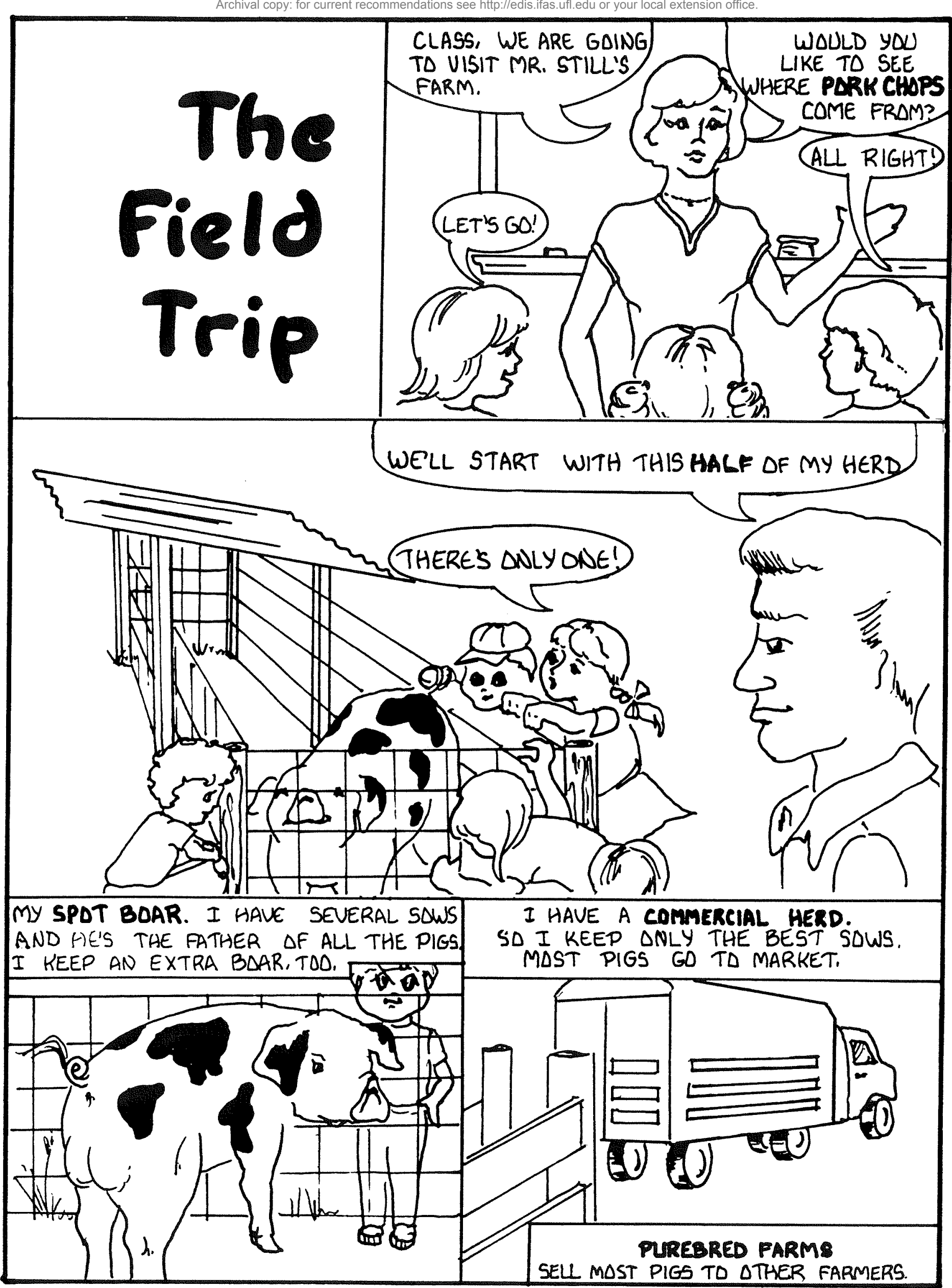




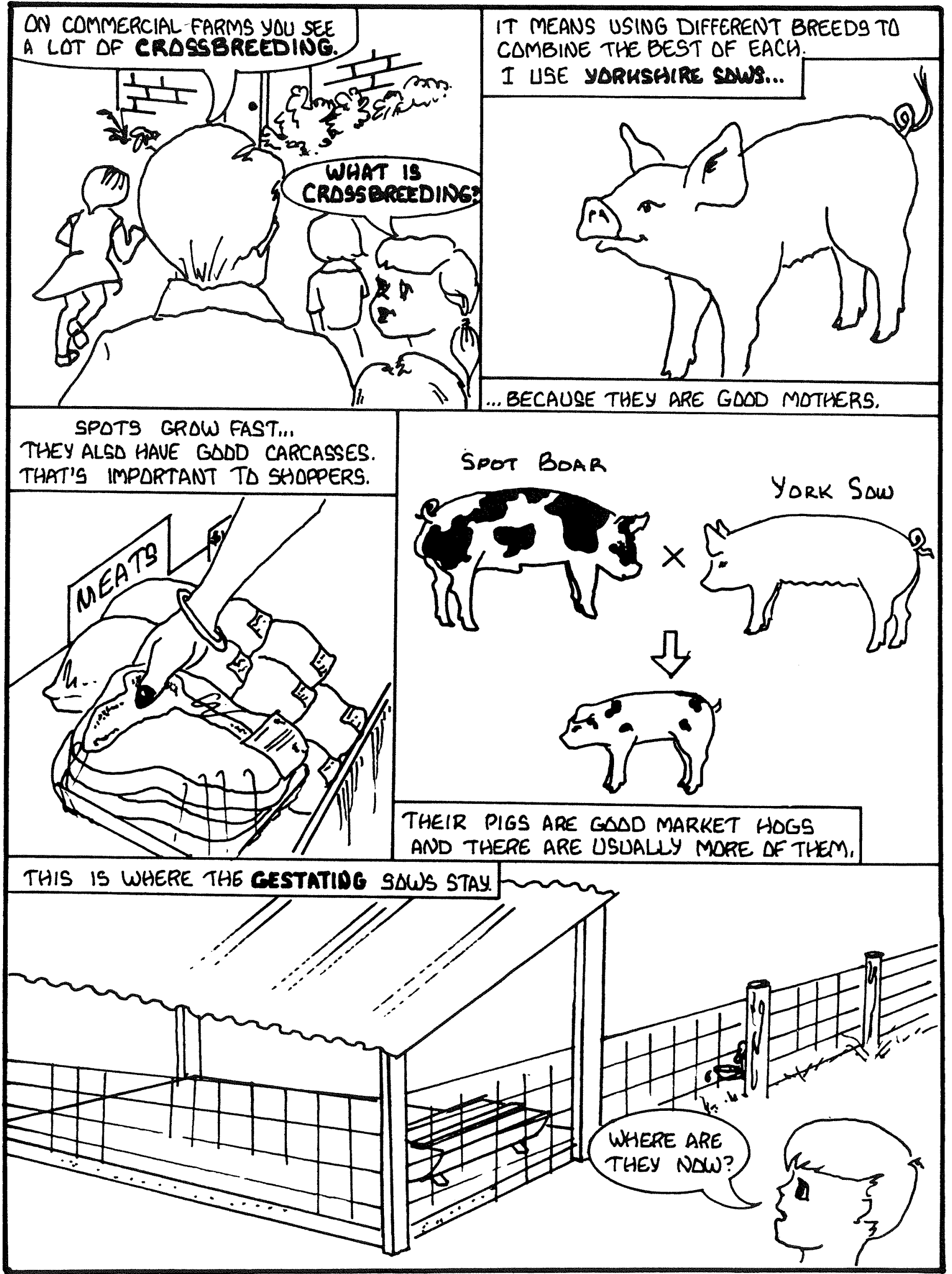




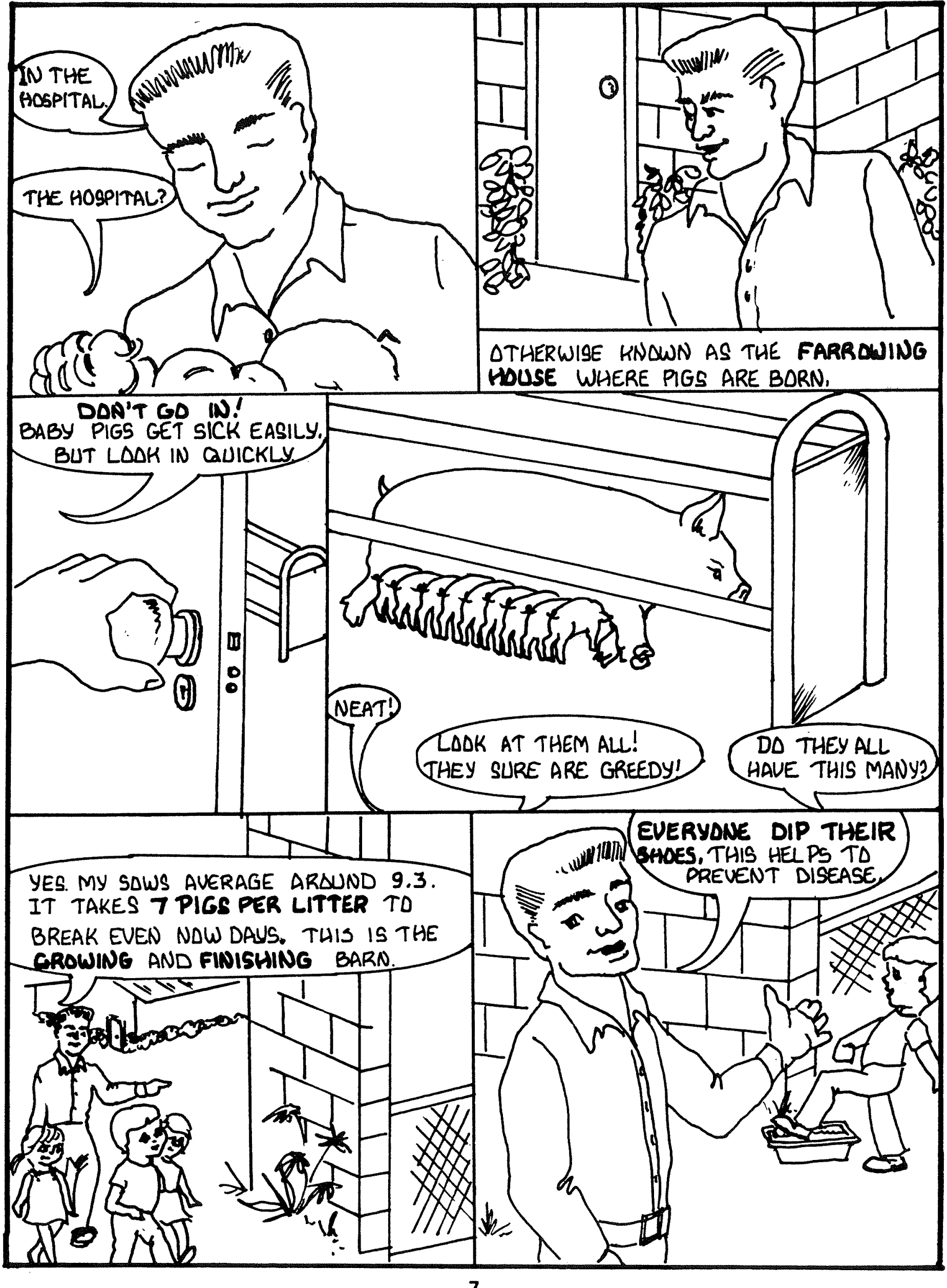




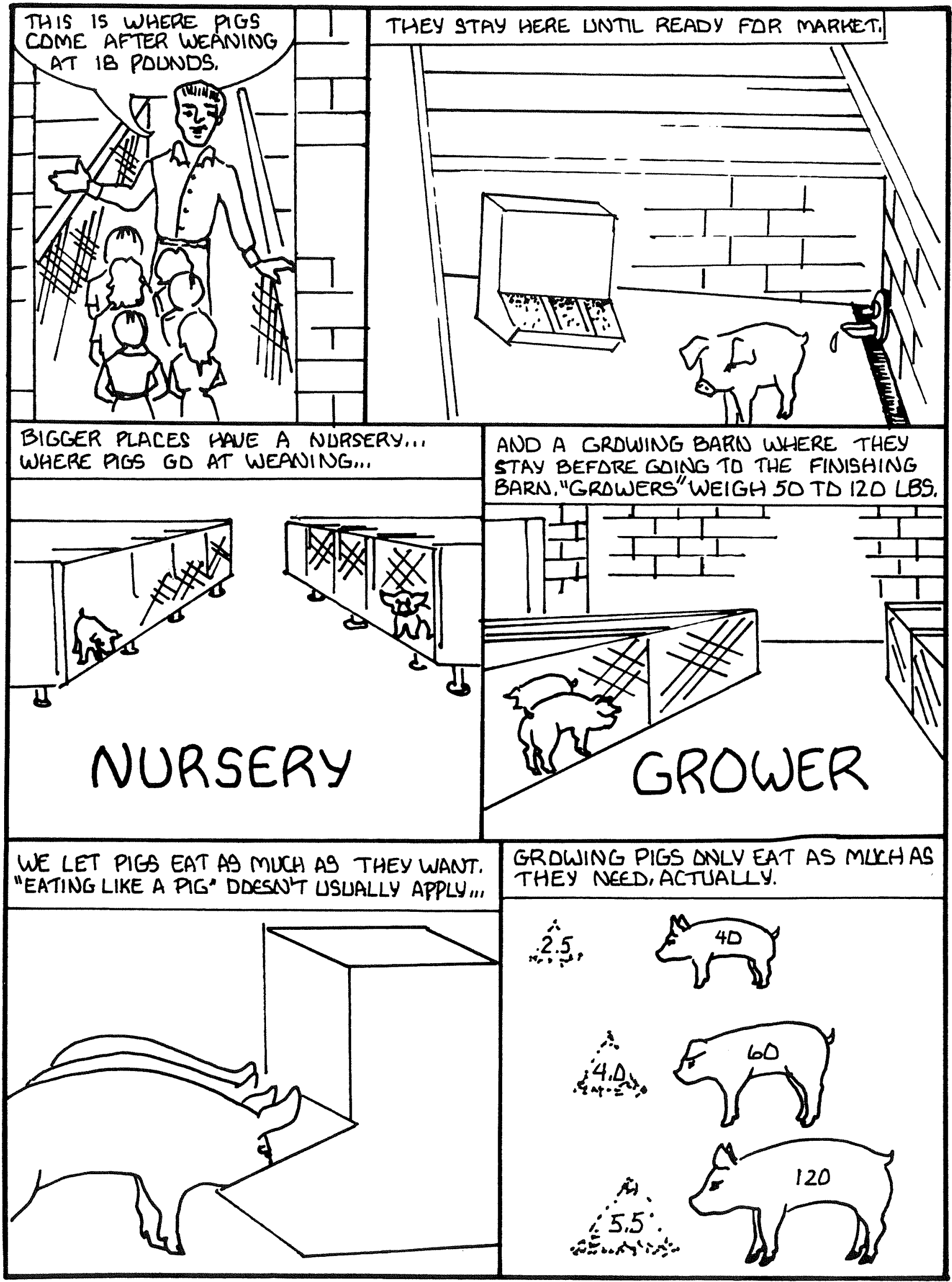




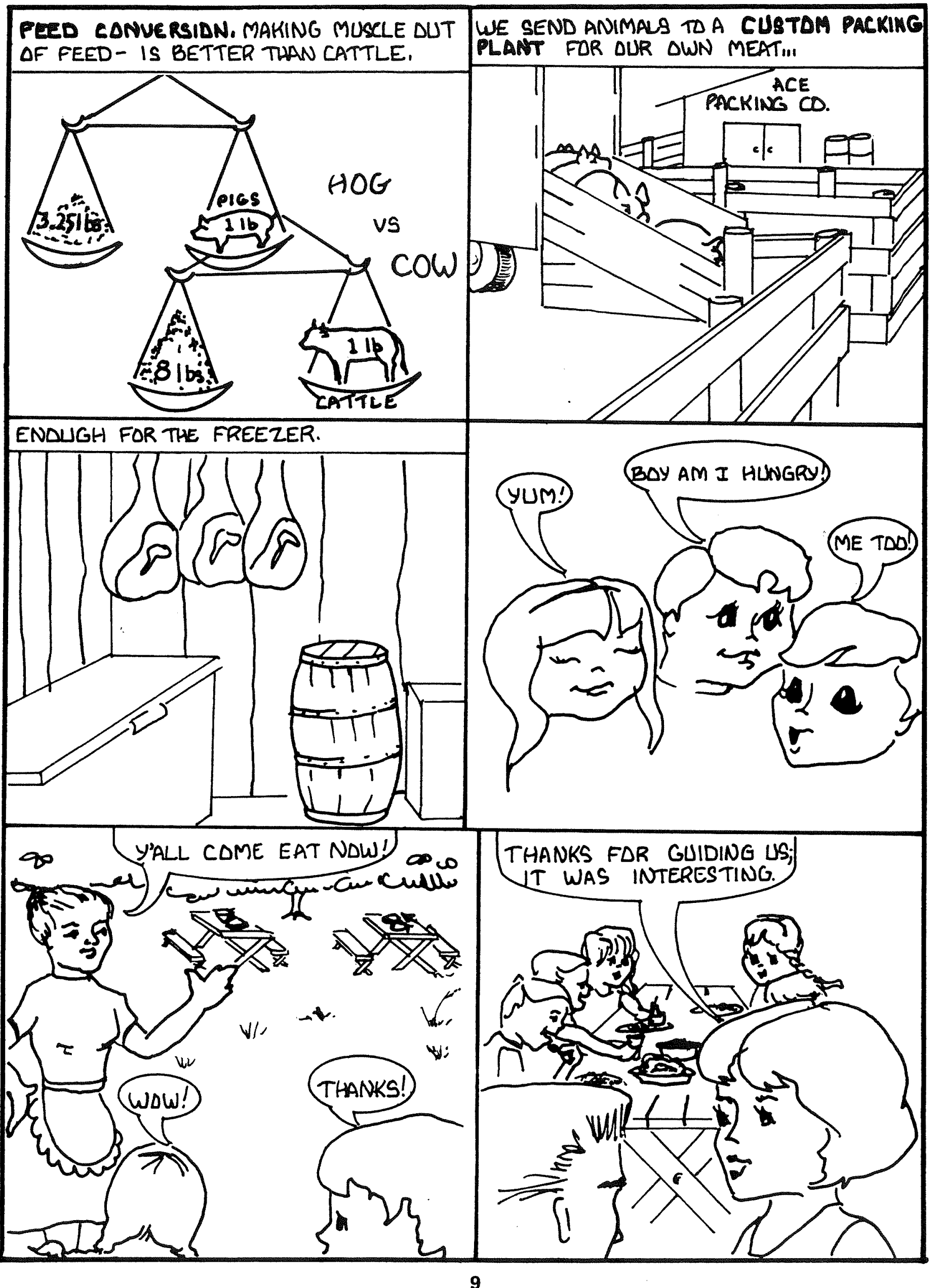




\section{Objectives}

The purpose of a market hog 4-H project is to achieve the following:

1. To acquire an understanding of and sound skills in market hog production by preparing for, purchasing, caring for and keeping records on one or more head of swine.

2. To be able to identify the types and grades of hogs and employ efficient methods of marketing.

3. To identify the degree of quality, the wholesale and retail cuts of pork and pork products and understand their importance to human nutrition.

4. To understand the business aspects and economics of purchasing animals, feed, facilities and equipment for a swine project.

5. To develop integrity, sportsmanship, coordination and ability to speak in public through participation in related activities, such as demonstrations, talks, judging events, tours and exhibits.

6. To develop leadership abilities, build character and assume citizenship responsibilities.

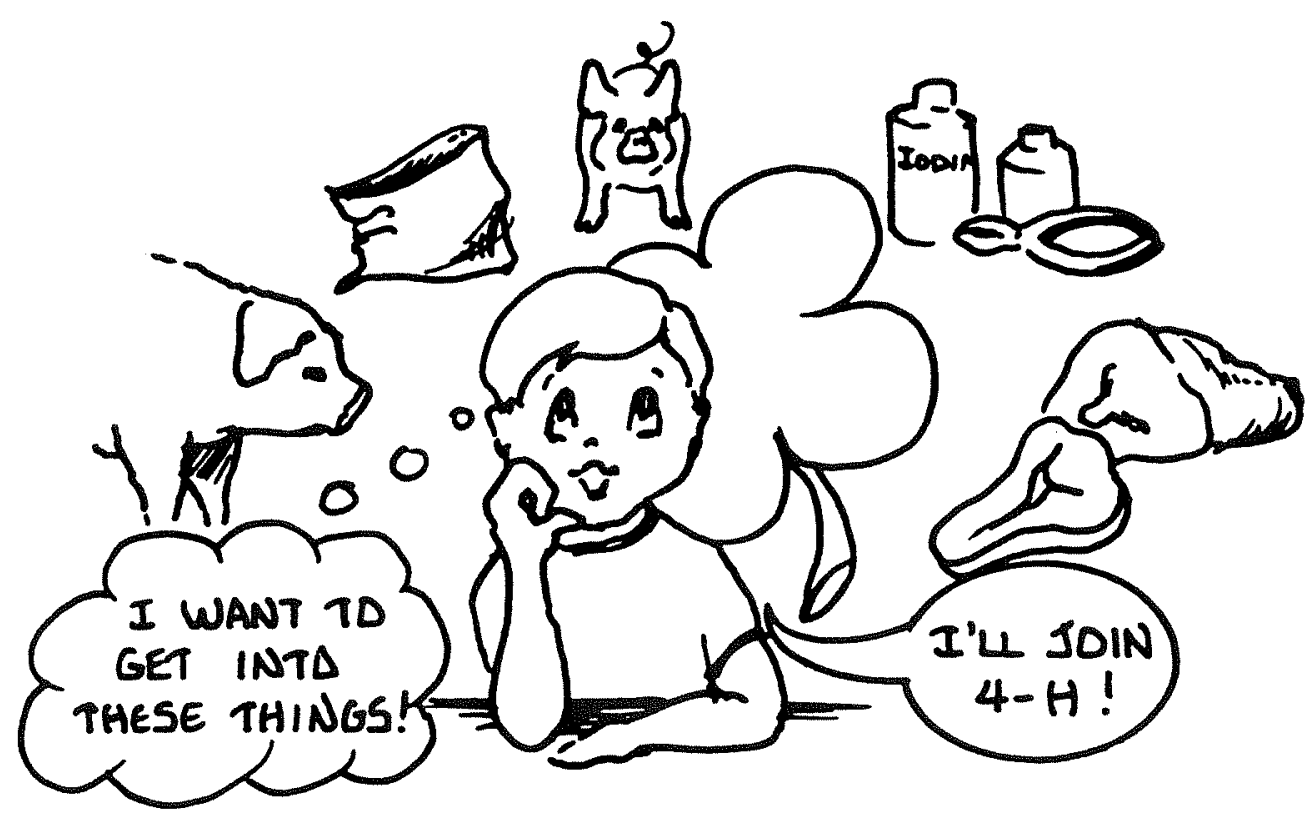




\section{Getting to Know DSRECS}

\section{Breeds}

There are eight major breeds, but three are much more popular than the others. These are Yorkshires, Durocs and Hampshires, For more about them and the other breeds, you can write the breed associations at the back under References

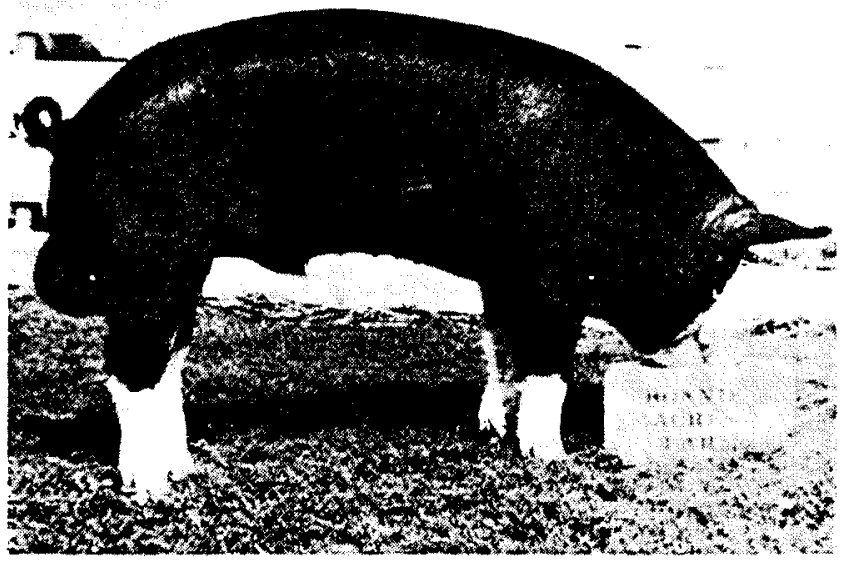

Berkshire: Black with six white points (nose, tail and legs), these pigs have erect ears and a short, dished snout. They work well in confinement.

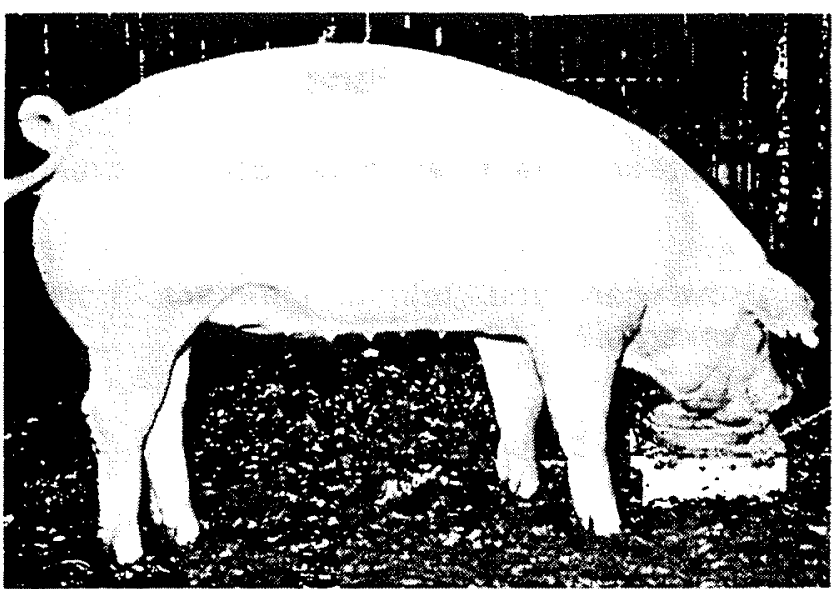

Chester White: Solid white, these pigs have medium sized, droopy ears. They usually have large litters.

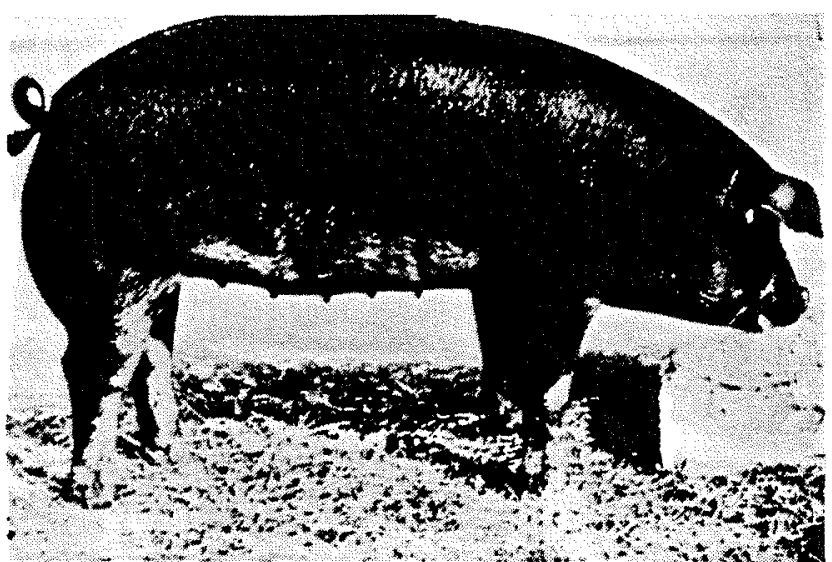

Duroc: These red hogs have droopy ears. They grow fast and have good feed efficiency.

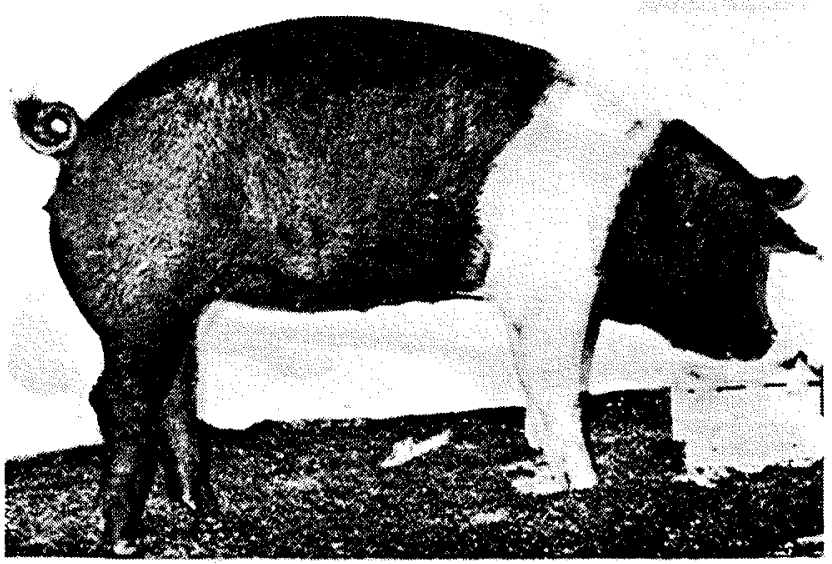

Hampshire: Black with a white belt, they have erect ears and are popular because of their meaty carcasses

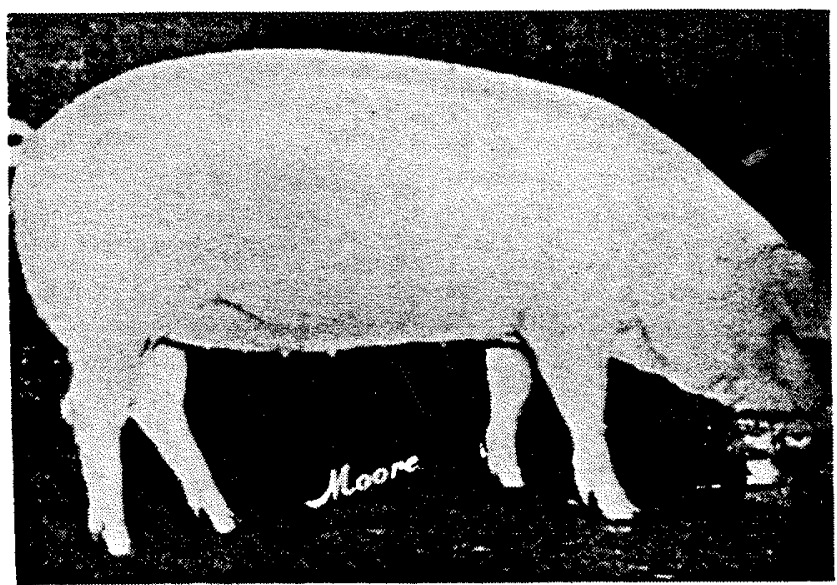

Landrace: Like the other white swine, this breed is known for the sows' mothering ability. They have very large, floppy ears. 


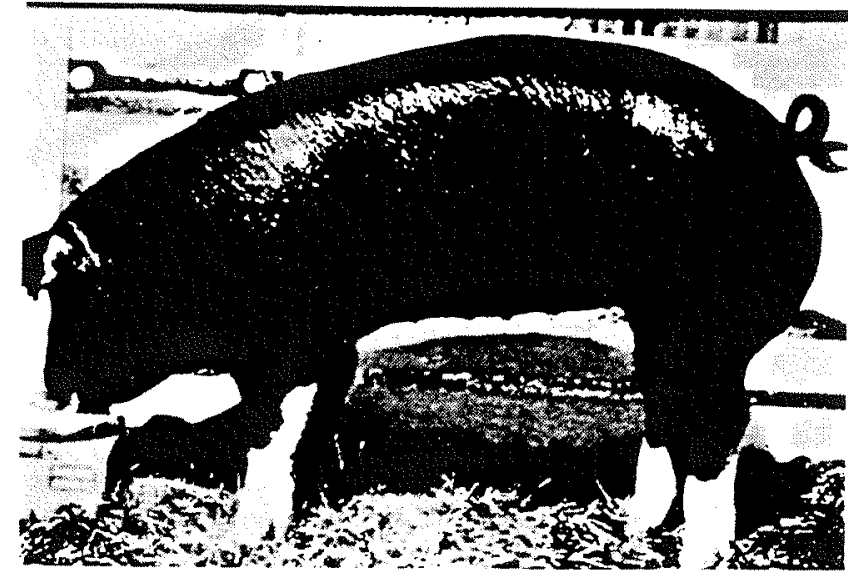

Poland China: Like the Berkshire, this breed has six white points on a black body. They have medium sized, droopy ears and produce meaty carcasses.

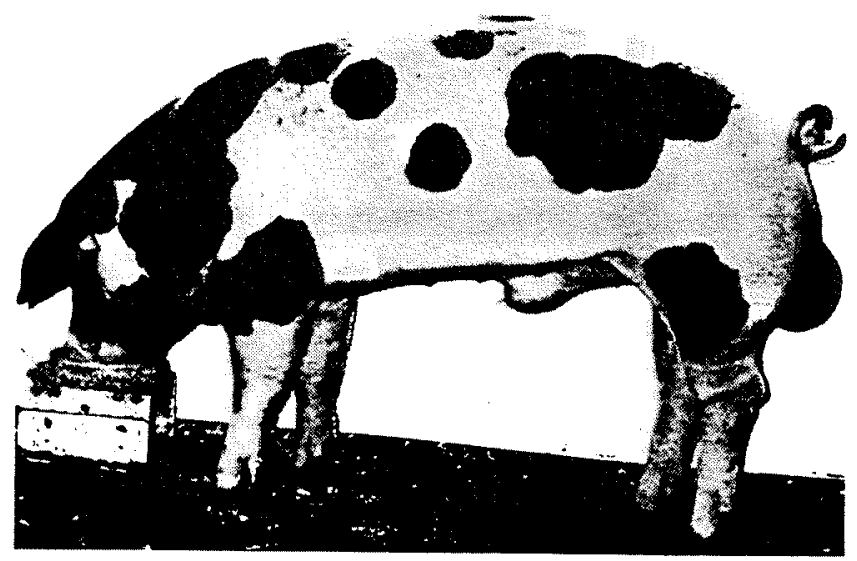

Spotted Swine: These used to be called Spotted Poland Chinas. They are white with black spots and have the same type of ears as Chinas. The breed is known for producing pigs that grow fast.

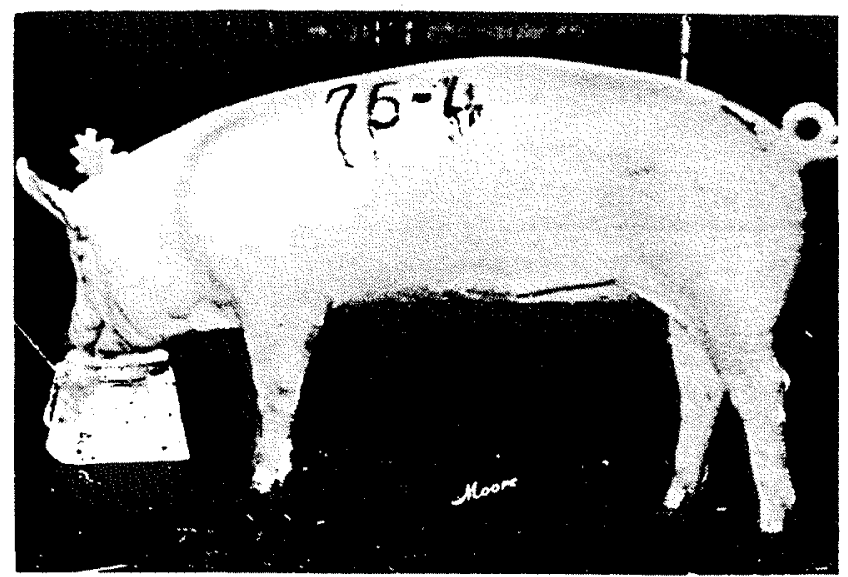

Yorkshire: the most popular breed, Yorks are good mothers and produce large litters. They are white with large erect ears.

\section{Crossbreeding}

These eight breeds are also important because they are most often used in crossbreeding programs. If you want crossbred pigs, choose breeds that balance each other. Yorkshire and Duroc, or Chester White and Spotted Swine are two possible crosses. As a rule of thumb, use white gilts and dark boars. See the illustrations below for examples of two different kinds of crosses.
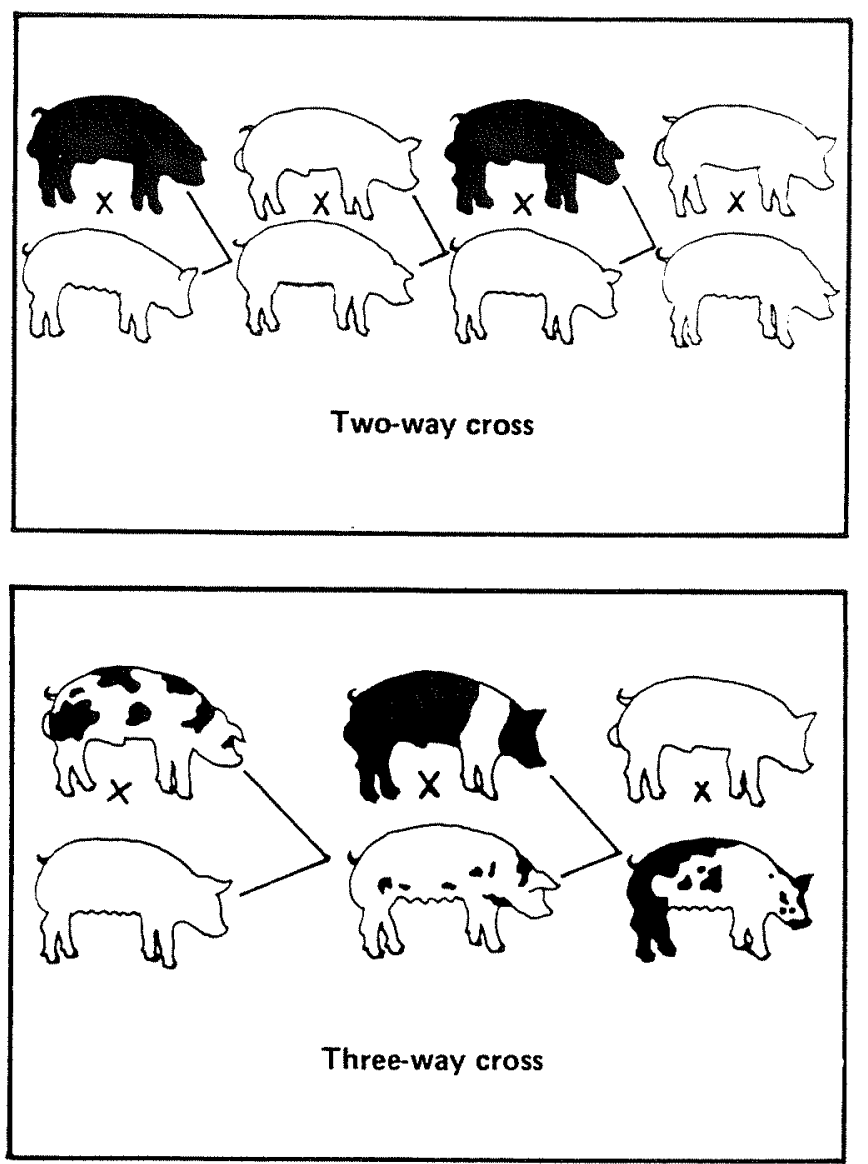

\section{Questions}

1. What are the three most popular breeds?

2. How can you tell a Landrace from a Yorkshire?

3. What are Durocs known for?

\section{Activities for You}

Write to the associations for information on different breeds. Report to the club and/or give a speech. 


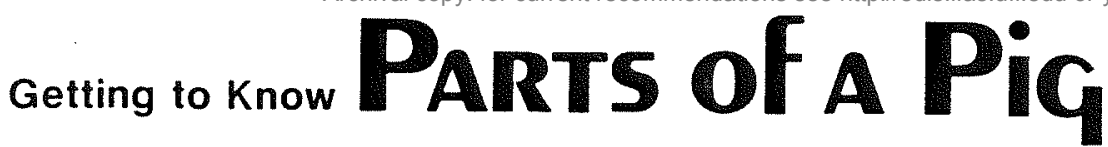

Learn the parts of a pig. This helps you describe your pig and you will know what other people are talking about, too. Also learn the four lean cuts of a pork carcass: the ham, loin, Boston butt and picnic. The following charts give this information.
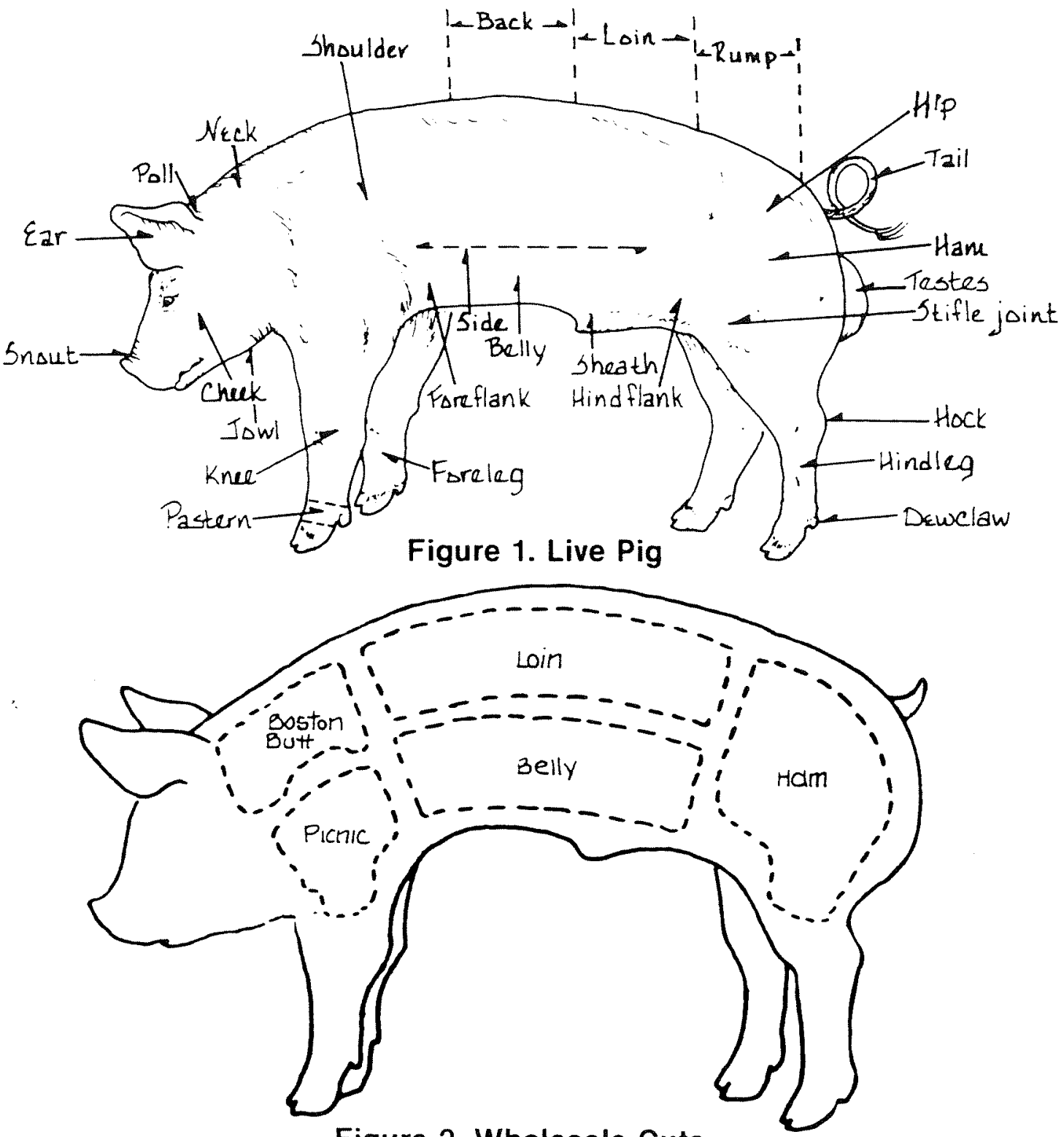

Figure 2. Wholesale Cuts

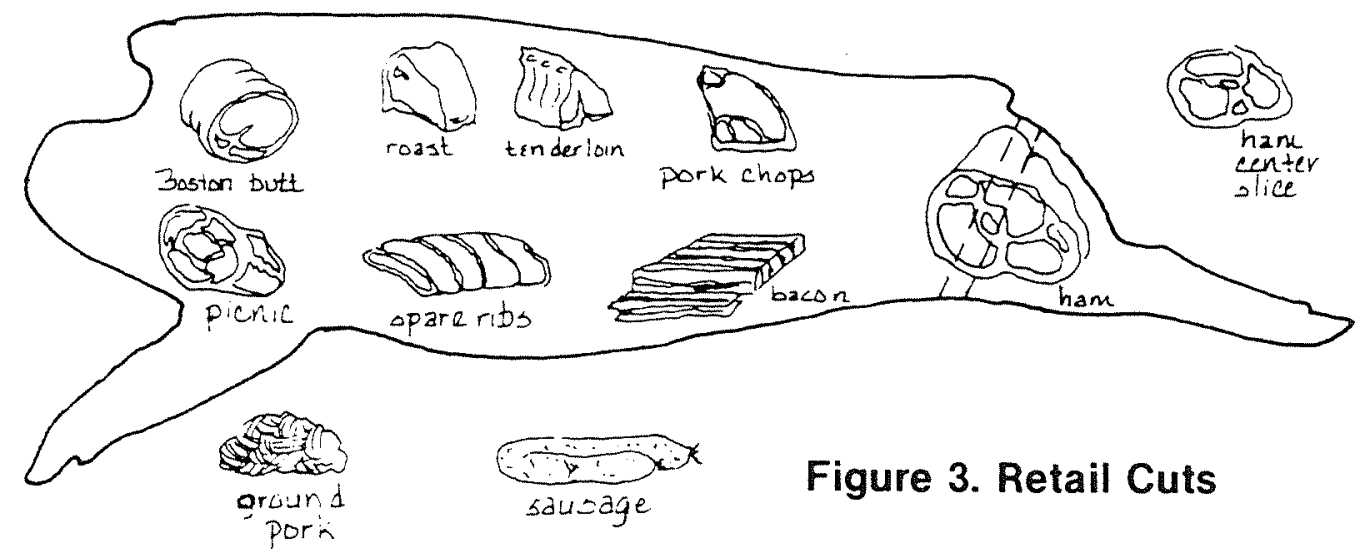




\section{Activities}

1. Label parts of the live pig. Figure 1, at the bottom of page using numbers to fill in blanks.

2. Label wholesale cuts of pig. Figure 2, on the next page using numbers to fill in blanks.

3. Label retail cuts of meat, Figure 3 , on the next page using numbers to fill in blanks.

Parts of Live Pig
1. Back
6. Foreflank
11. Hip
16. Neck
21. Shoulder
2. Belly
7. Foreleg
12. Hock
17. Pastern
22. Side belly
3. Cheek
8. Ham
13. Jowl
18. Poll
23. Snout
4. Dewclaw
9. Hindflank
14. Knee
19. Rump
24. Stifle joint
5. Ear
10. Hind leg
15. Loin
20. Sheath
25. Testes

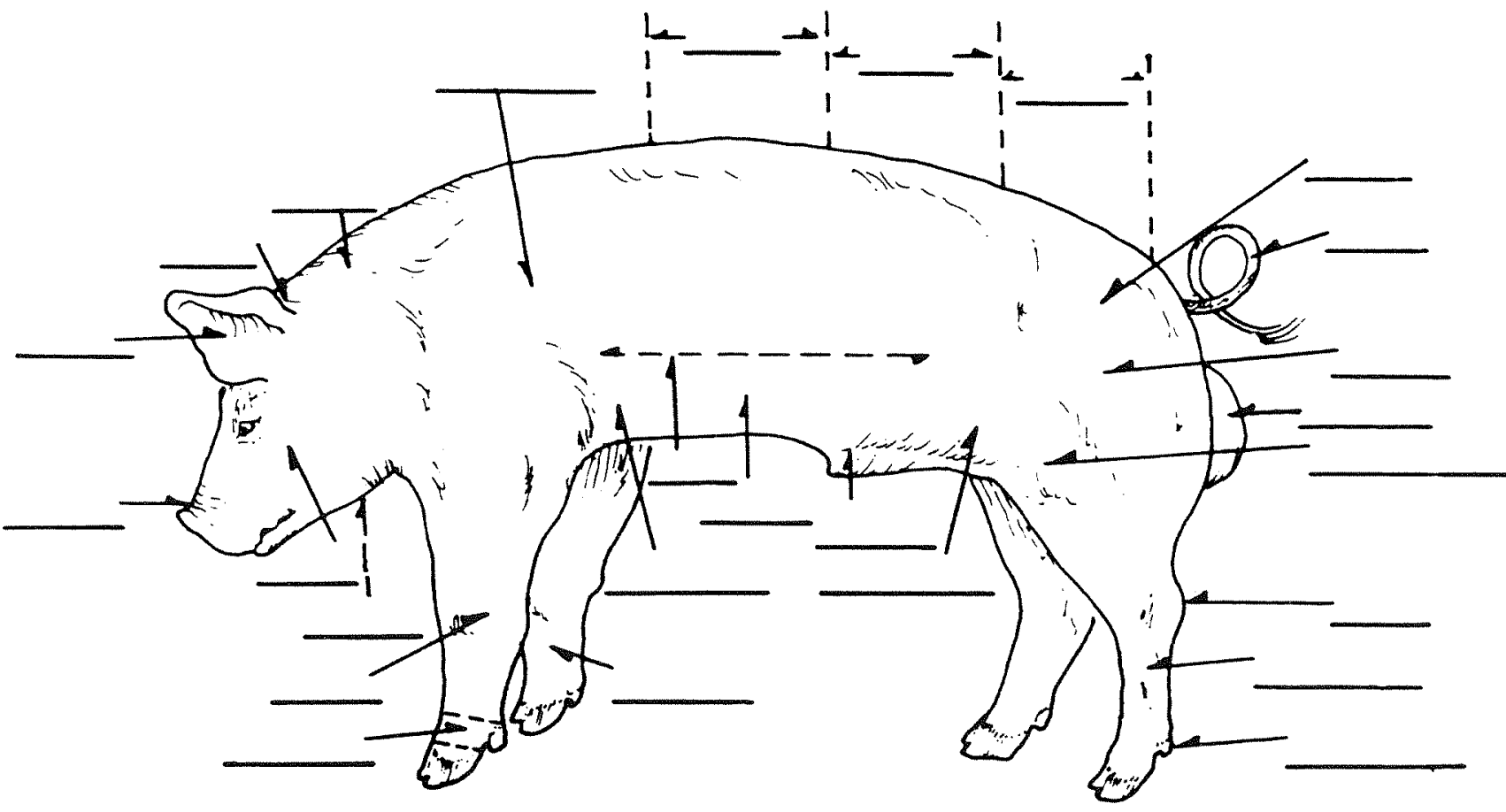

Live Pig 
Wholesale Cuts

1. Belly

2. Boston butt

3. Ham

4. Loin

5. Picnic

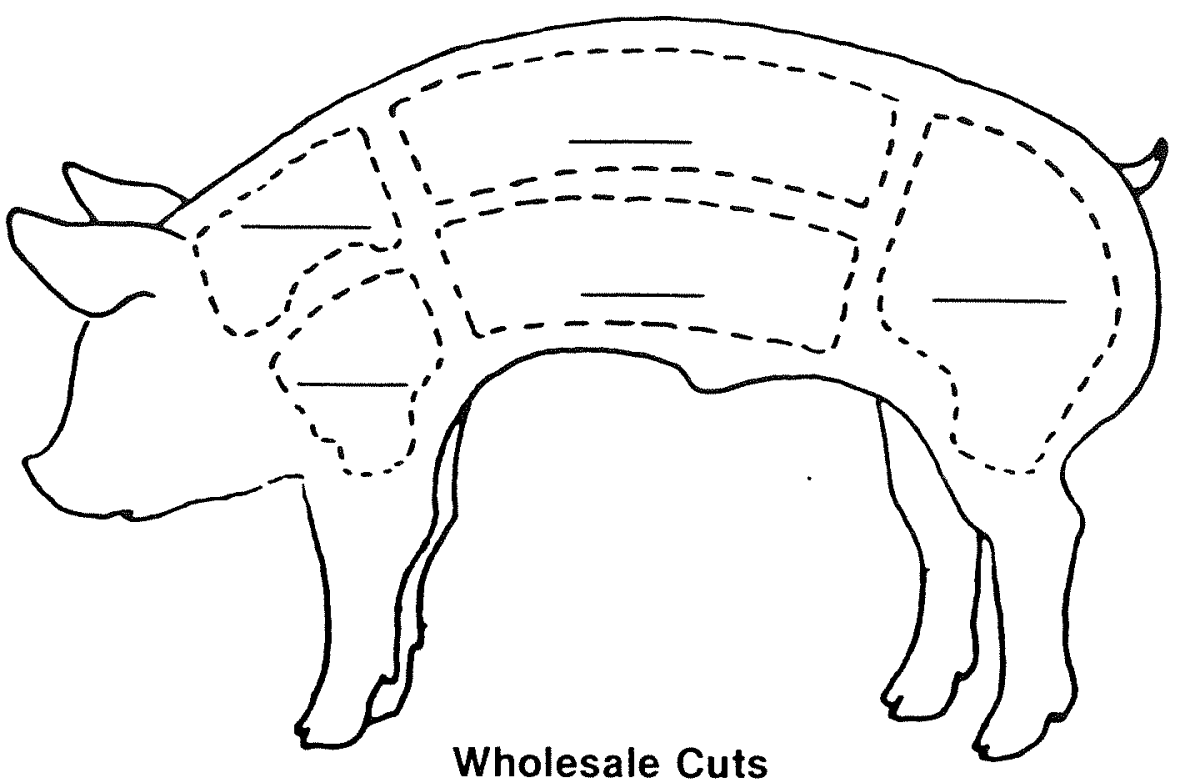

\section{Retail Cuts}

1. Bacon

3. Ham

5. Pork chops

7. Spareribs

9. Ground pork

2. Boston butt

4. Picnic

6. Roast

8. Tenderloin

10. Sausage

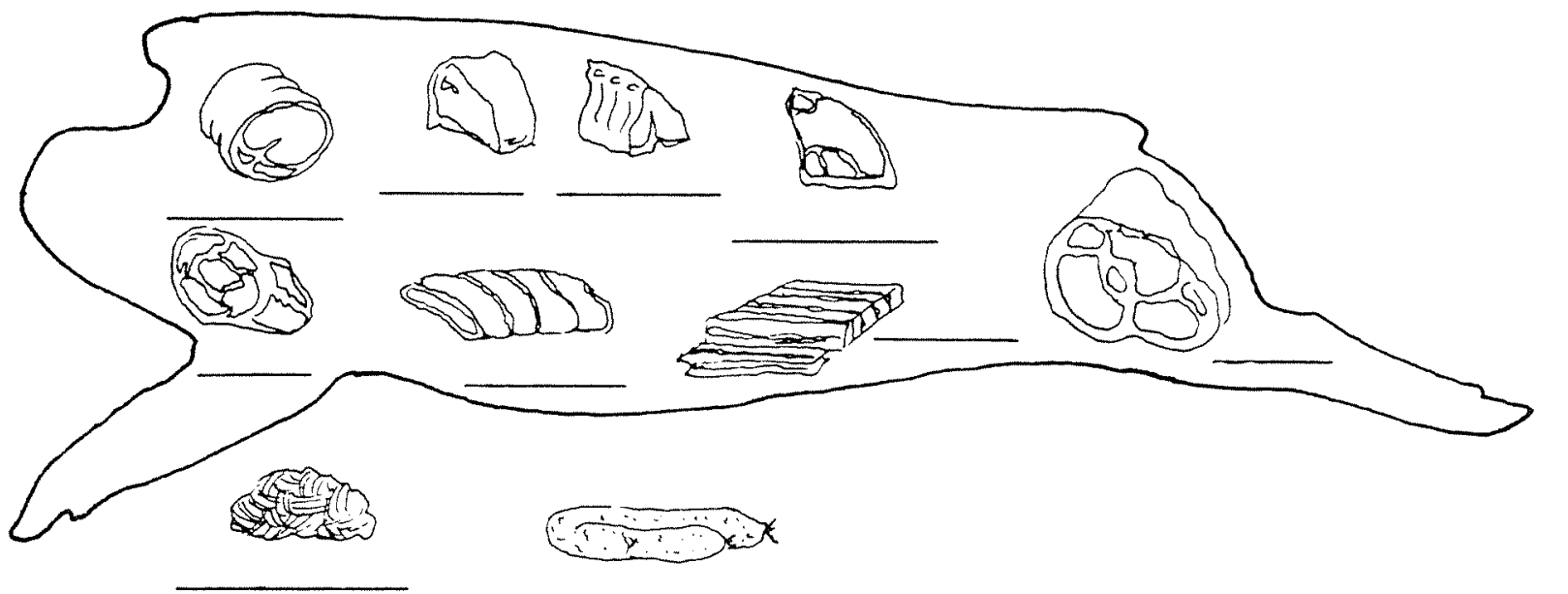

Retail Cuts 


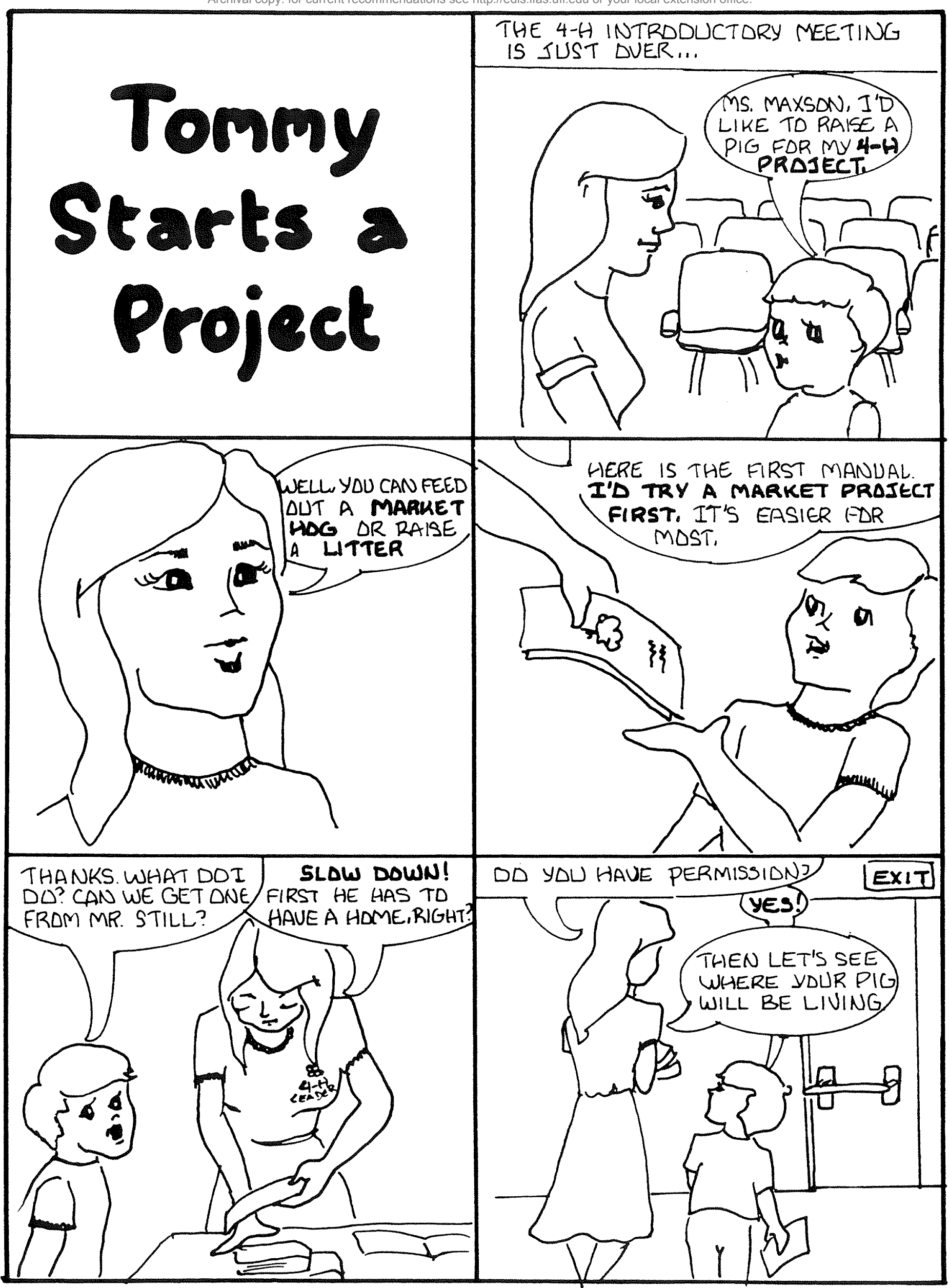




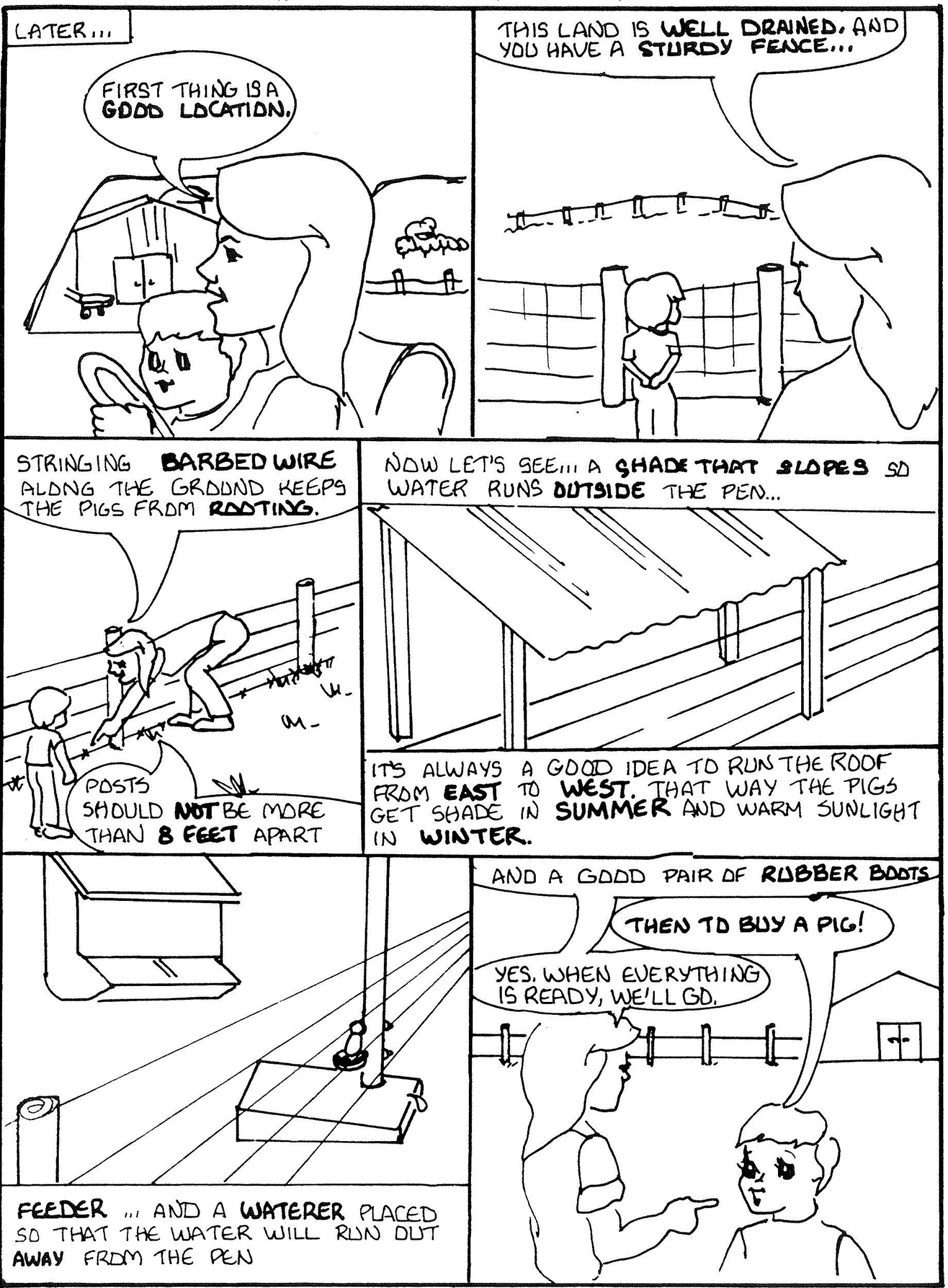




\section{PREPARING FOR YOUR PROJECT}

\section{Getting Ready}

Before you bring your pig home, you need to be ready for him. Use this list to make sure everything is done.

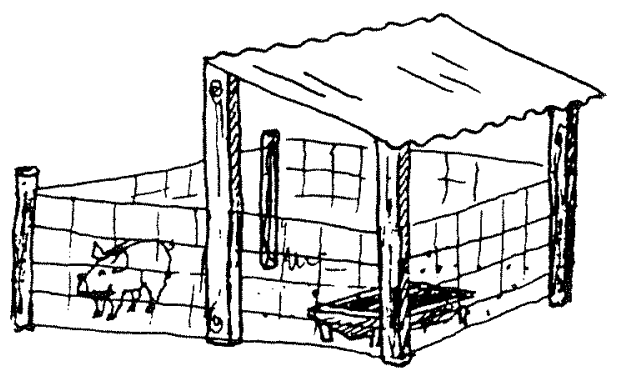

Pen

- 15 sq. ft. per pig

- $8 \mathrm{sq}$. ft. of shade per pig (made so he has shade all day)

\section{Location}

- downwind of the house (ask your parents)

- well-drained (no large mudholes when it rains)

- fenced with hog wire (5-strand) or other hogproof fencing

- trees

- separate from other pigs if possible
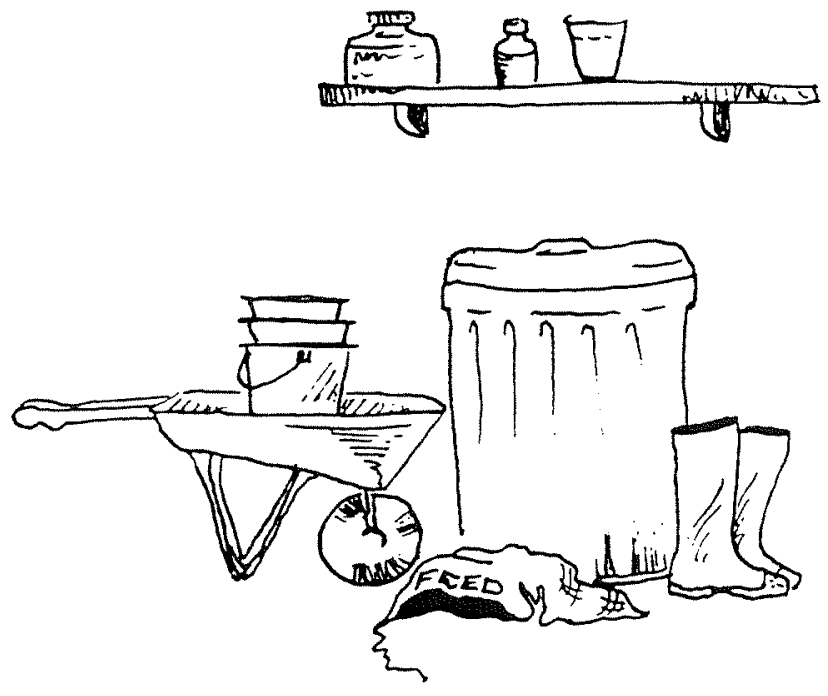

\section{Equipment}

- storage space

- feed buckets

- feeder or feed trough

- water trough

- closed container for feed bags

- wheelbarrow and shovel

- dewormer

- spray for lice and mange mites

- rubber boots

\section{Feed}

- $18 \%$ protein starter

- oats, bran or epsom salts

- fresh water

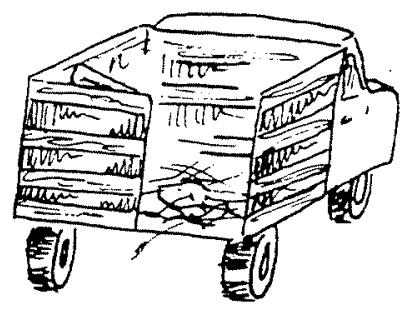

\section{Transportation}

- clean and with straw or wet sand for bedding

- secured so pig cannot jump out

- all sharp edges padded to prevent injury

\section{Questions}

1. How much space does a growing pig need?

2. Name three pieces of equipment needed to take care of a pig.

3. Why do you put bedding in a truck when you are moving pigs?

A. To prevent slipping.

B. To prevent injury.

C. Both of the above.

4. Why is fence put on outside of posts?

\section{Activities for You}

Visit other club members to see how they take care of their pigs. 


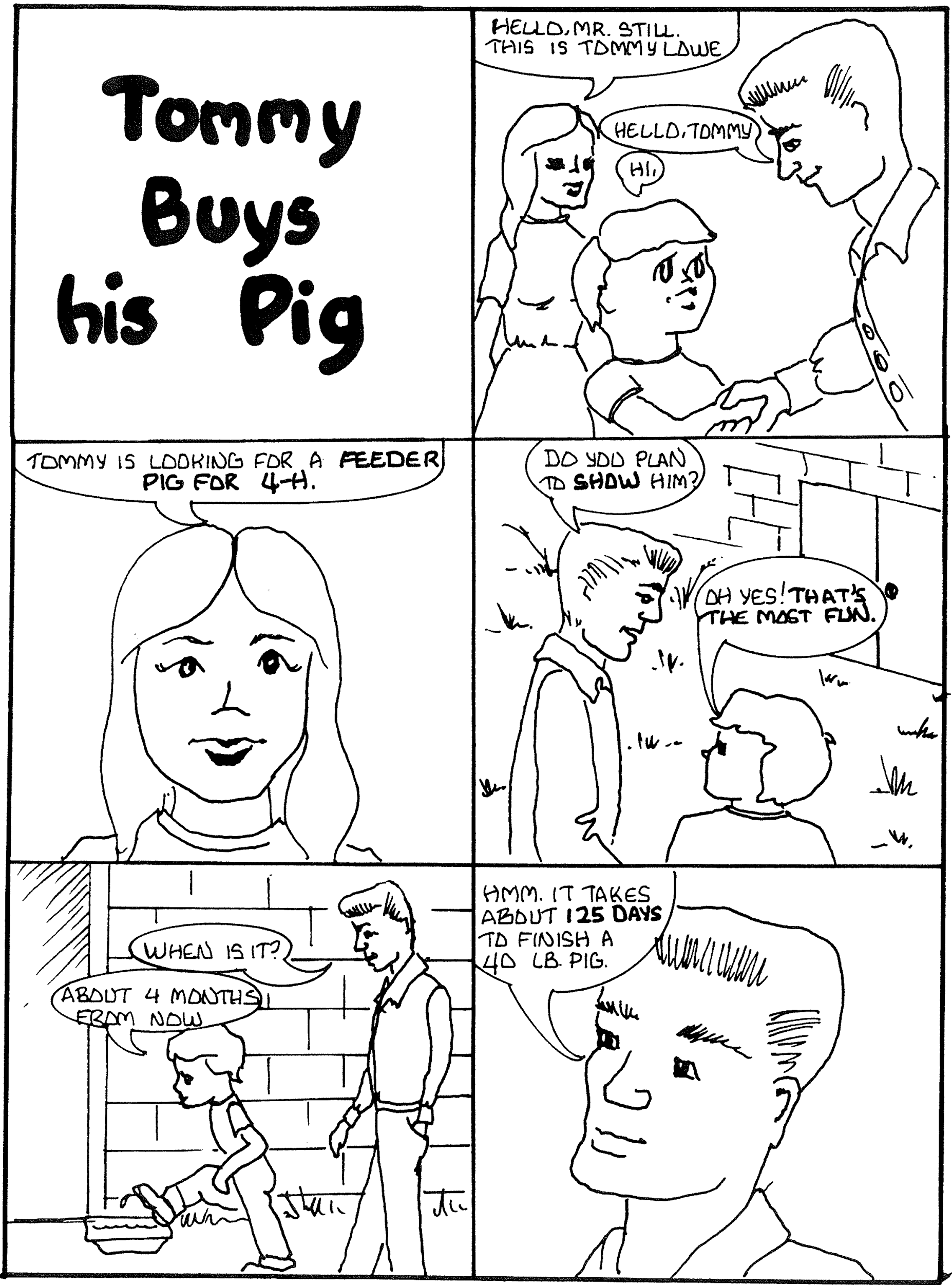




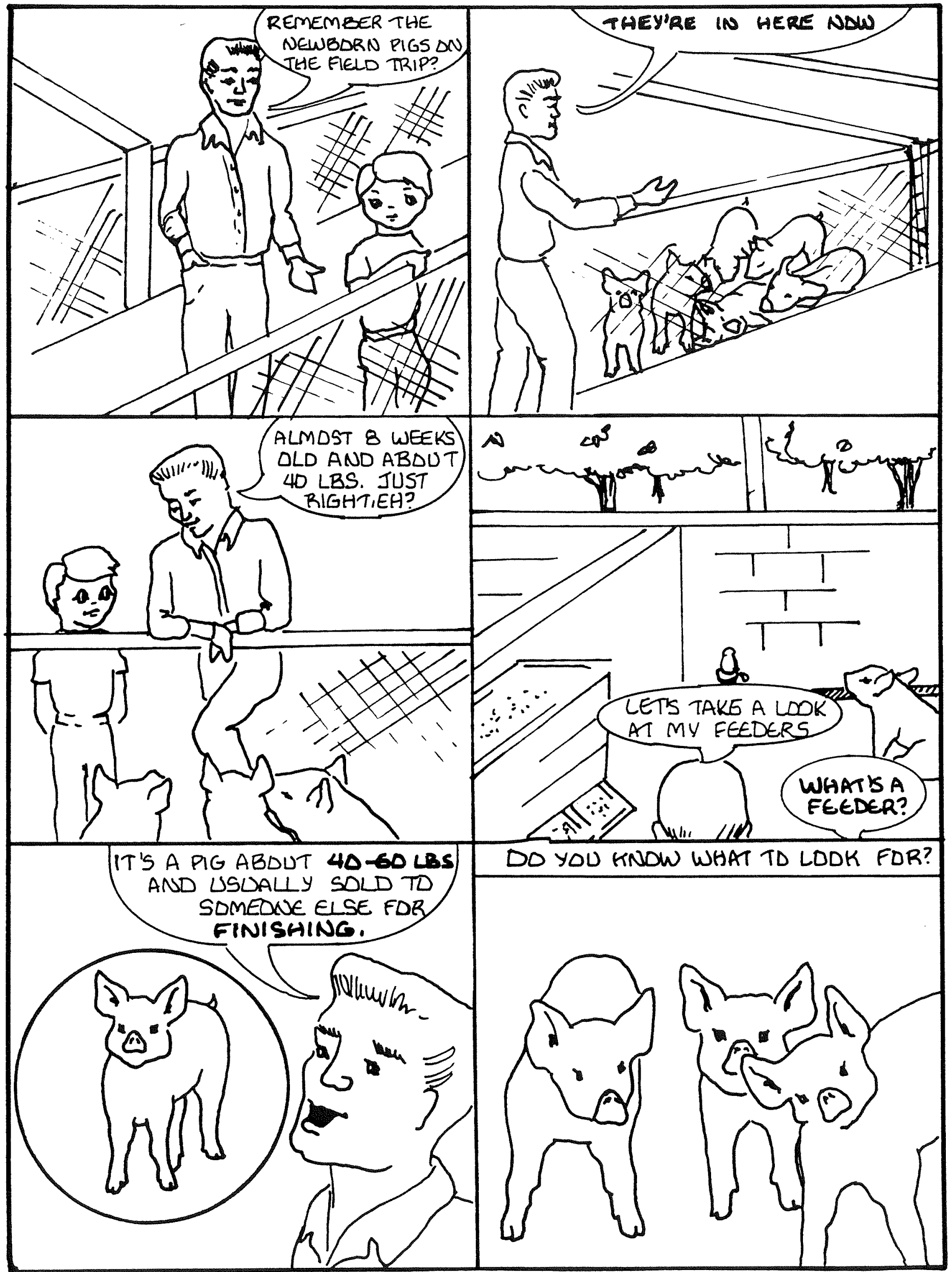




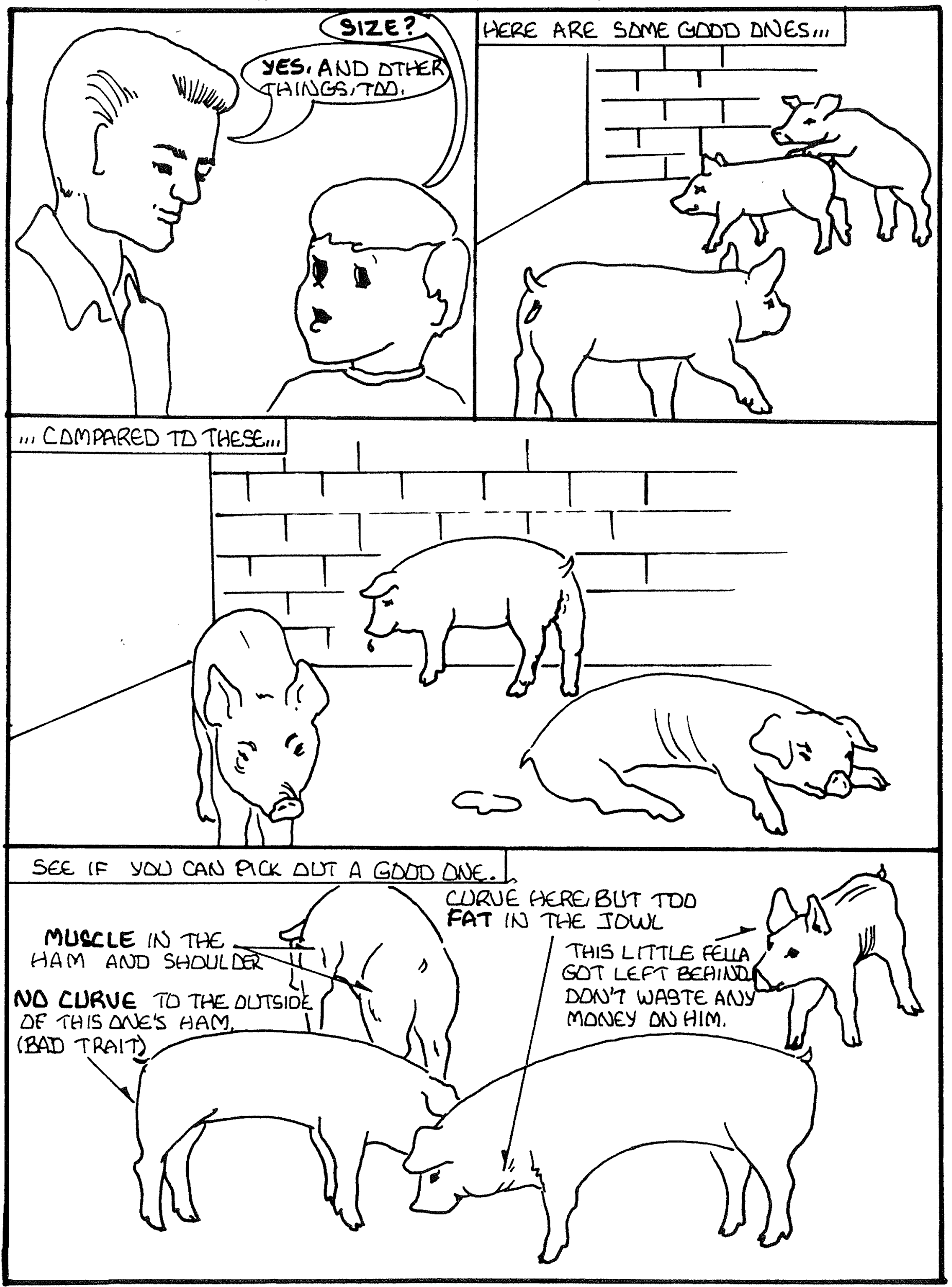




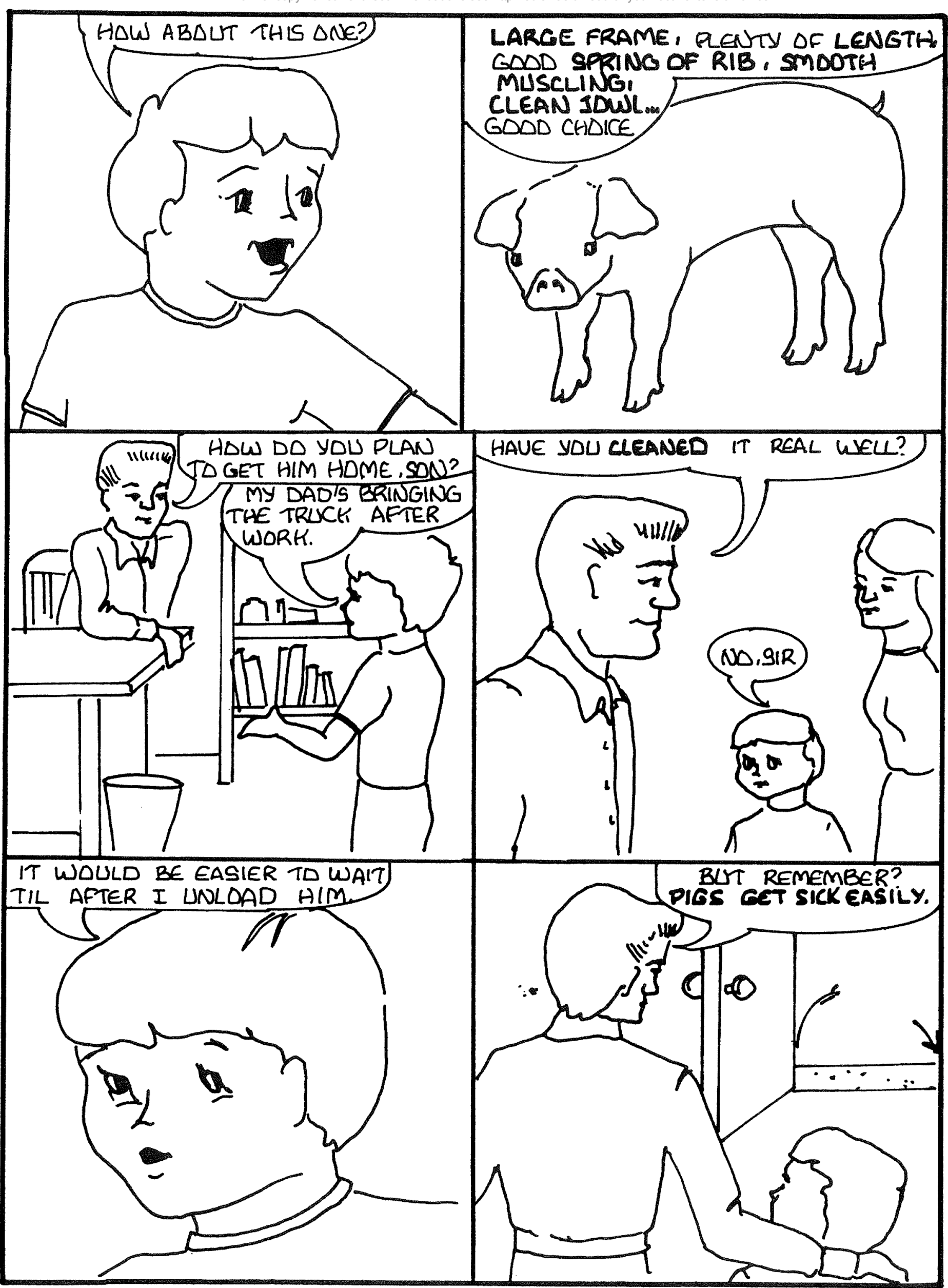




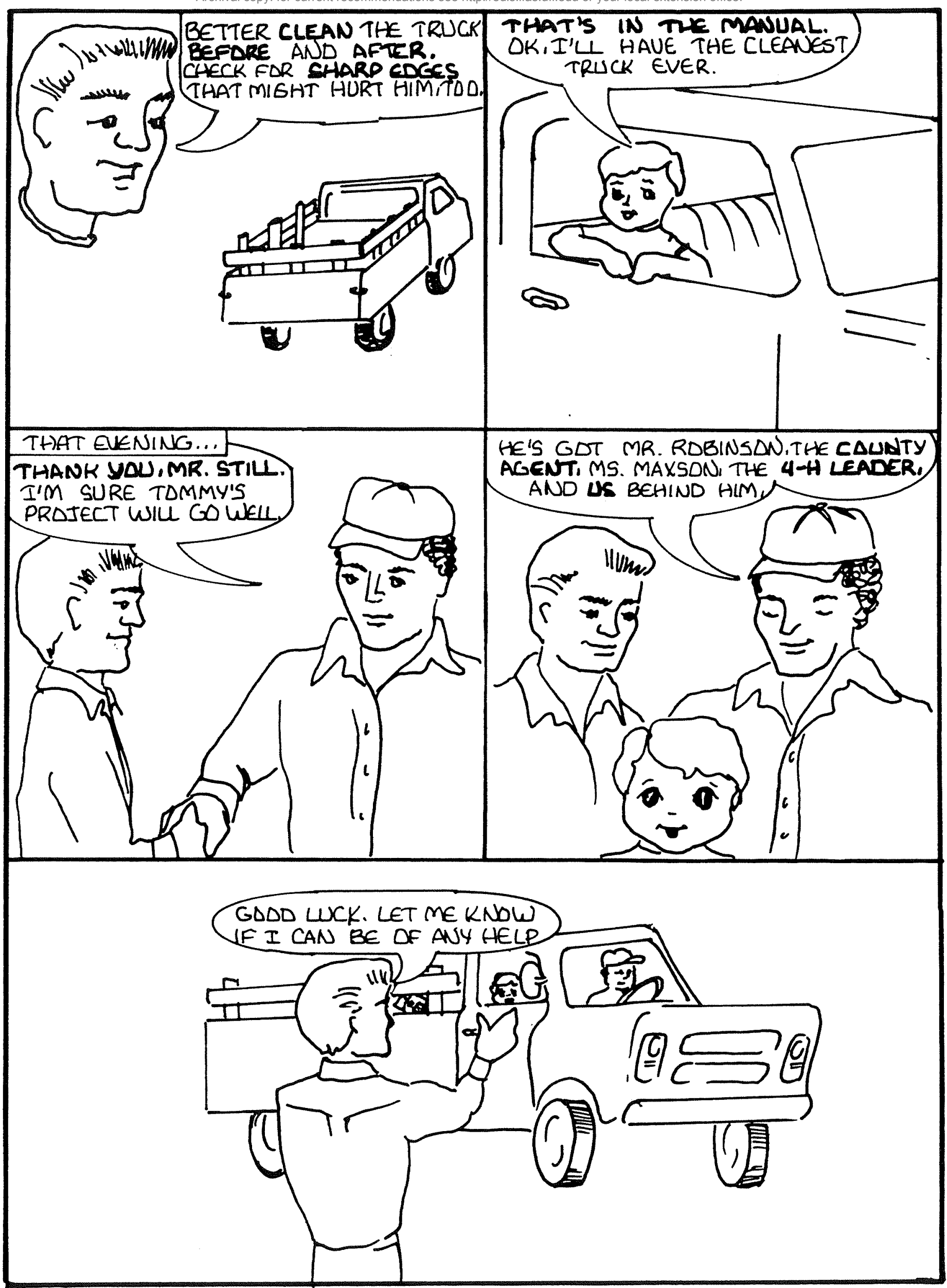




\section{SELECTING YOUR PIG}

Once you have his home ready, you can begin looking for your pig. There are several places to go.

In North and Central Florida, feeder pig sales are held almost every Friday at one of the livestock auction markets. However, recognize that pigs from auction markets are mixed from many locations and thus more likely to come in contact with diseases. Another problem at auctions is that generally feeder pigs are sold in groups.

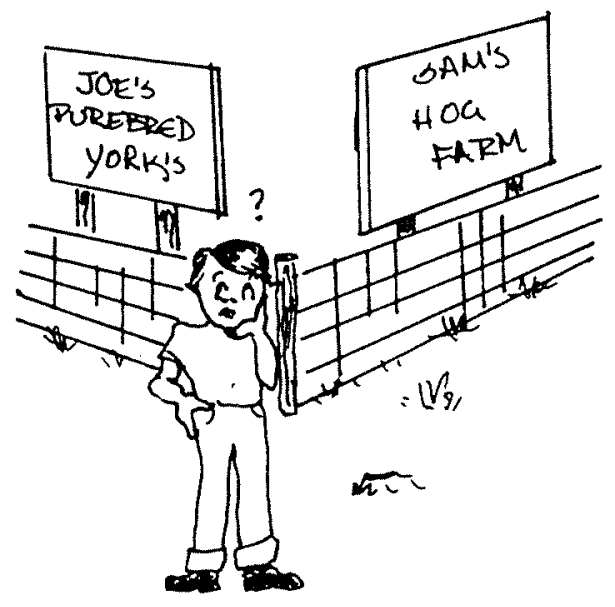

You would be better off to buy a pig from a commercial or purebred farm in your area. This way you know how your pig has been treated and what he has been fed. If you want to raise purebreds in the future, buying market pigs from a purebred breeder may be a good idea. You will get to know more about the breed and it shows your interest to other breeders. However, crossbred hogs usually have a better chance in shows.

Take along someone who knows pigs the first few times you go looking. It takes time to develop an eye for good ones. Follow the guidelines in Tommy Buys his Pig and take your time. Do not settle for one that is almost what you want"almost" does not count with judges. There are plenty of feeders and with a little effort you can find a good project pig.

When do you buy your pig? How old should he be? How much should he weigh? Use the guide that follows to figure it all out.

\section{If you buy a pig weighing this much}

$30 \mathrm{lbs}$.

40 lbs.

50 lbs.

\section{it should take about this long before he is ready to show.}

Of course your pig may gain a little faster or slower, depending on his ability and your care. Keep in touch with your leader and county agent. Add about a week to the days above to take care of delays and weight loss due to moving. By counting back from the show date, you can tell when you need to start your project.

\section{Questions}

1. If the county show is the last Thursday in October, when should show pigs be bought?

2. Name two bad traits in pigs.

3. Name three good traits to look for in pigs.

4. Name two places you can buy feeder pigs.

\section{Activities for You}

Try out for your county Judging Team. 


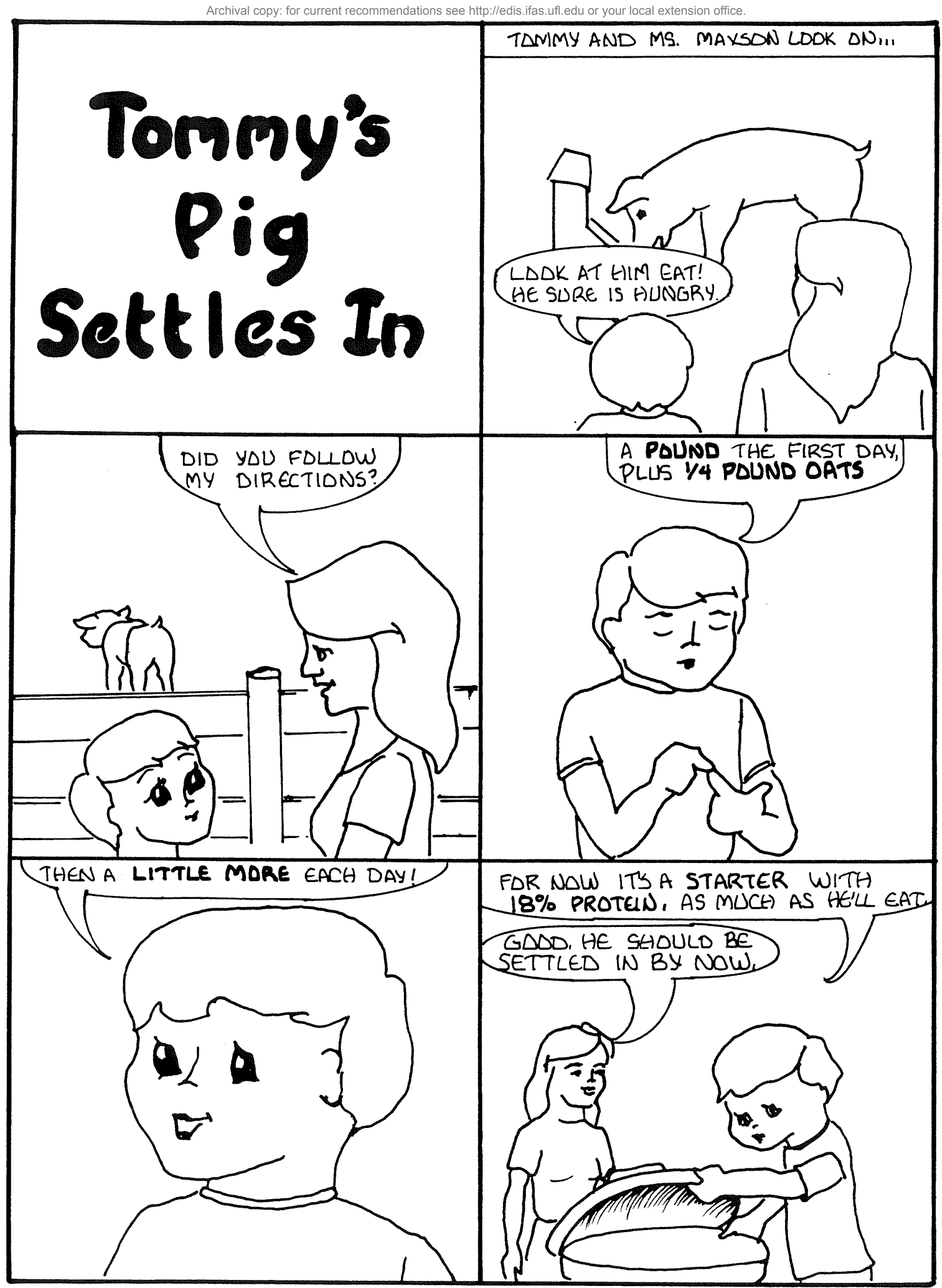




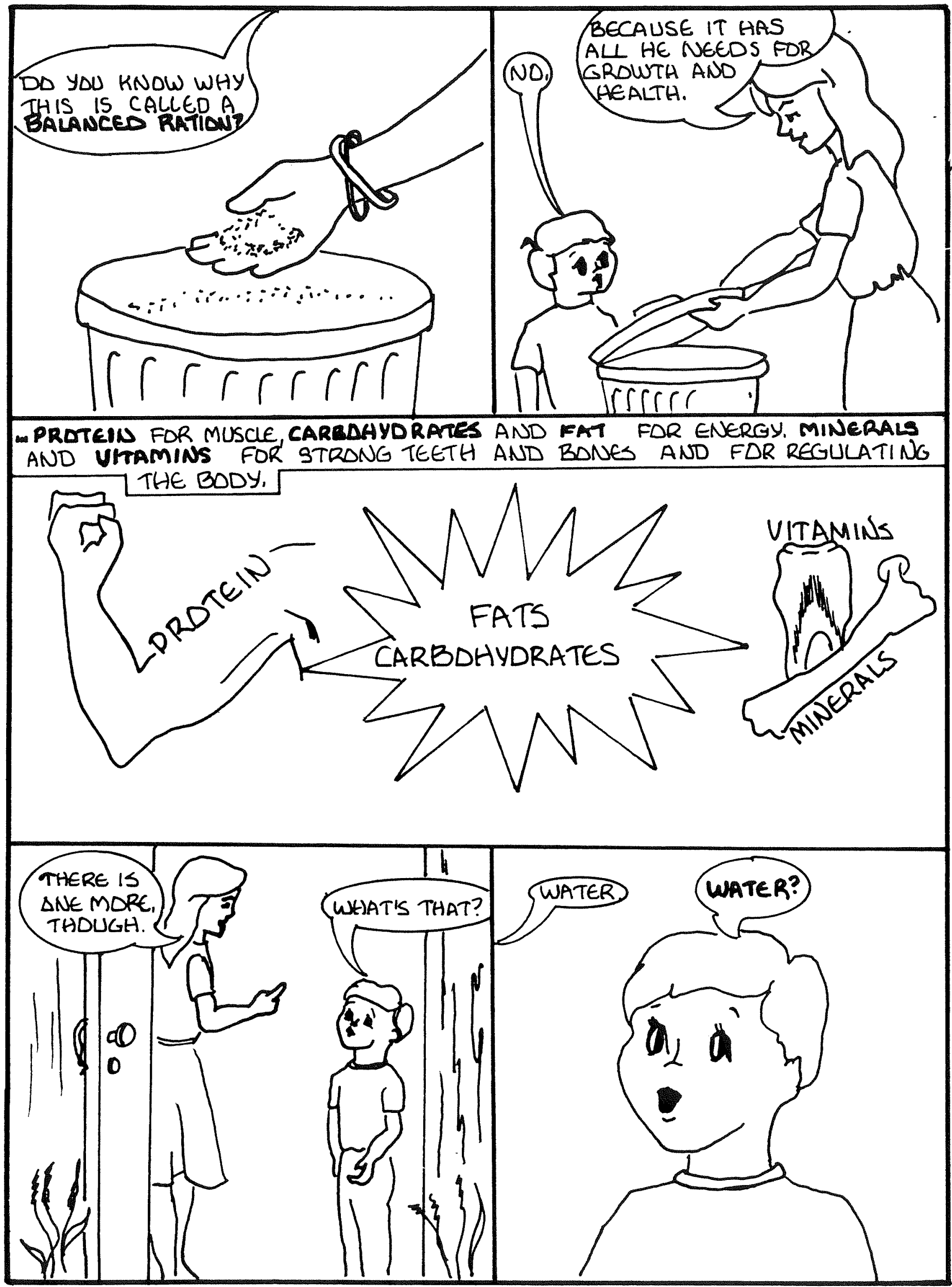




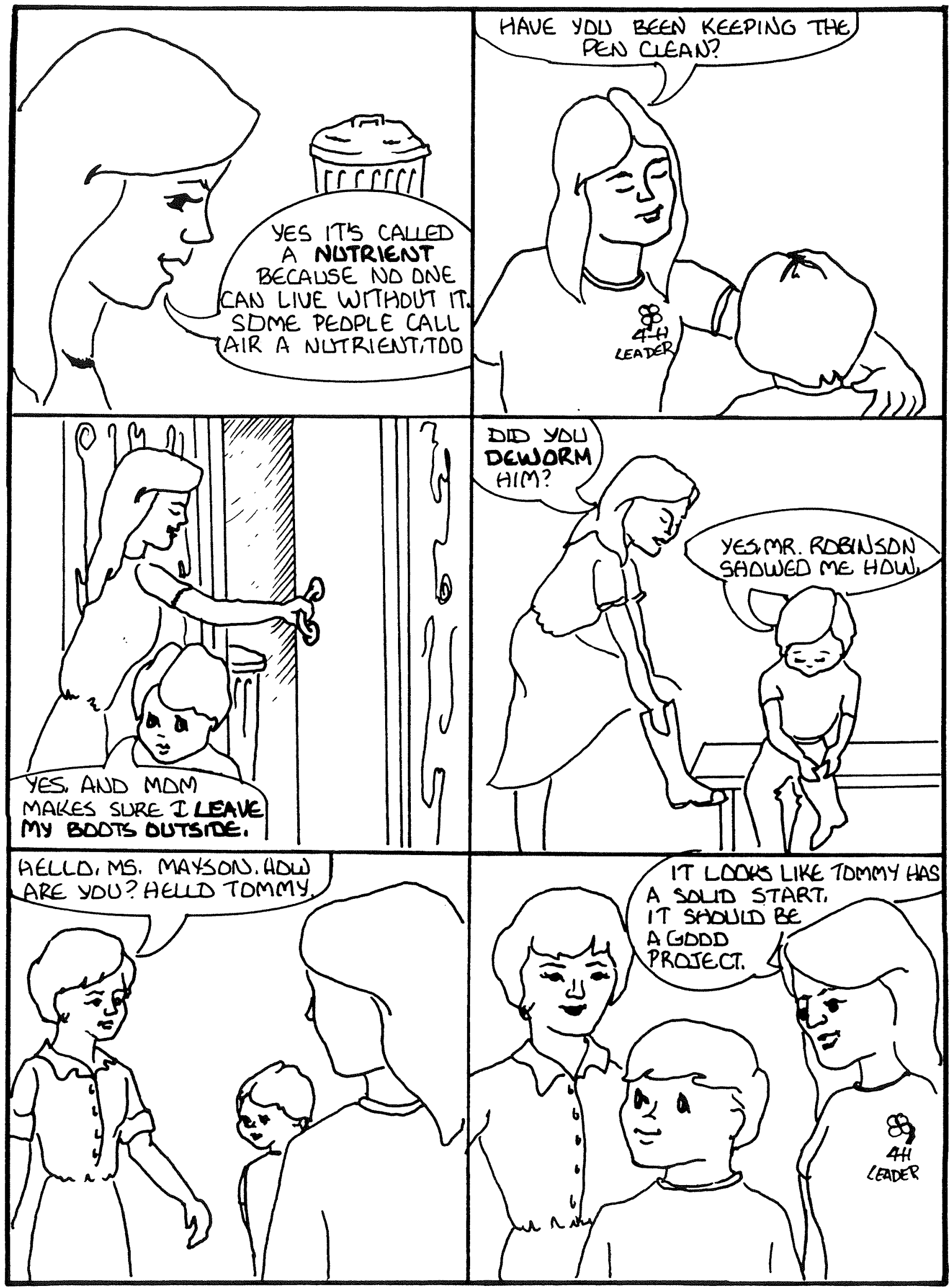




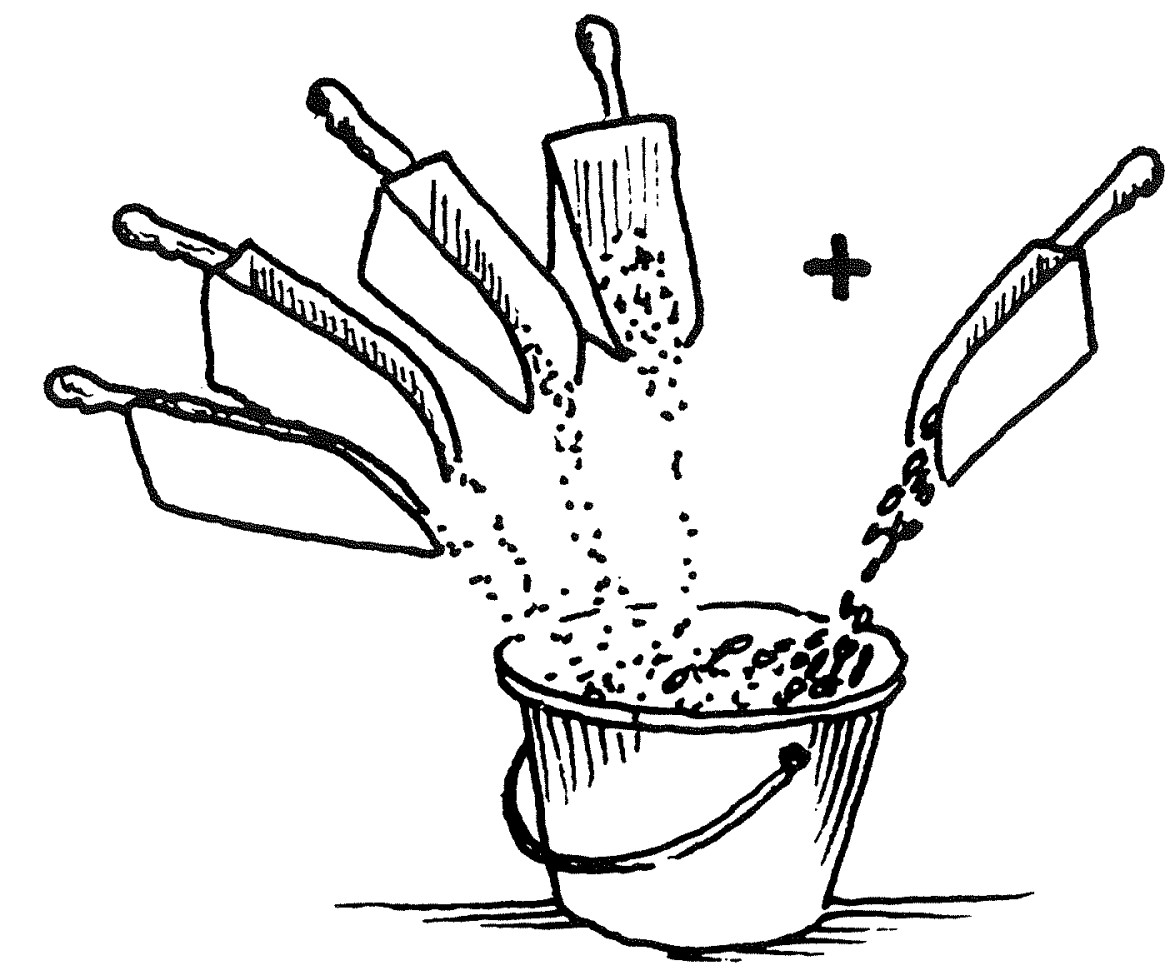

\section{CARE OF YOUR PIG}

\section{The First Days}

You can help your pig adjust to his new home. Keep his pen cleaned and give him lots of fresh water. Give your pig time to settle down and get used to everything. Talk to him and let him get used to you, but do not make a pet out of him. Judges do not like to see pet pigs in shows.

Mix about four parts $18 \%$ protein starter with one part oats. Bran can be used instead of oats, and if you cannot find either of them, one to two tablespoons of epsom salts can be substituted.

Give him about a pound of the feed the first day. Increase the amount of the mixture each day until he is eating as much as he wants. Then you can stop feeding oats. After he is settled into his new home use the following information to tell what kind of feed to give him.

\section{Feeding Your Pig}

Different size pigs need different rations. The table below gives you an idea of what kind of feed to get, but ask your leader or county agent for more details. If your parents feed hogs, go ahead and use what they feed.

\section{Protein Requirements}

25-60 lbs........ Starter ..... 18\% protein $60-120$ Ibs........ Grower ...... 16\% protein $120-220$ Ibs........Finisher...... 14\% protein

The next table will help you get some idea of how much feed you have to buy for your pig. Keep in mind these guides and your pig may need more or less.

\begin{tabular}{|lcccc|}
\hline Pig size & $\begin{array}{c}\text { Pounds of feed } \\
\text { per day }\end{array}$ & $\begin{array}{c}\text { Number } \\
\text { of days }\end{array}$ & $\begin{array}{c}\text { Feed } \\
\text { Total }\end{array}$ & $\begin{array}{c}\text { Gain } \\
\text { per day }\end{array}$ \\
\hline $40-120 \mathrm{lbs}$. & $2.5-5.5$ lbs. & 57 & $208 \mathrm{lbs}$. & $1.4 \mathrm{lbs}$. \\
$120-220 \mathrm{lbs}$. & $5.6-8.0 \mathrm{lbs}$. & $\frac{59}{116}$ & $\underline{\overline{585}} \mathrm{lbs}$. & $1.7 \mathrm{lbs}$. \\
& & & & \\
\hline
\end{tabular}




\section{Health}

Preventing disease is easier than treating a sick animal. The best way to do that is to keep things clean and keep people and animals away from your pig. However, some diseases are so hard to prevent that pigs are vaccinated against them. Erysipelas and atrophic rhinitis are the two major ones as far as market pigs are concerned. Your veterinarian or county agent can help you decide which shots your pig needs. Many times the farmer who sells the pigs has already taken care of it. Ask when you buy your pig.

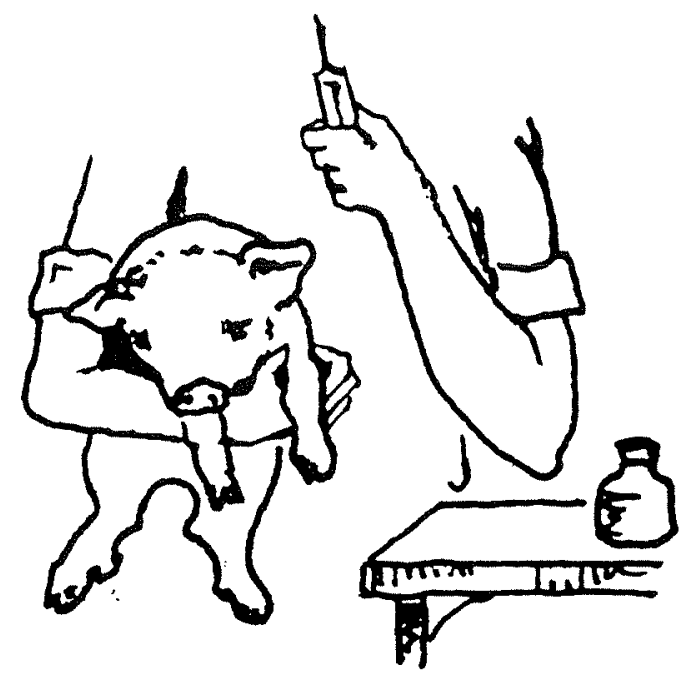

Another problem, especially in Florida, is worms. They live in the gut of a pig, stealing his food and maybe making him sick. Pigs should be dewormed when they are eight weeks old and again when they weigh $120 \mathrm{lbs}$. Ask the farmer if your pig was dewormed before you bought it. If not, ask him what you should use, or ask your leader. If ticks, lice or mange mites are found, ask your leader what to use also.

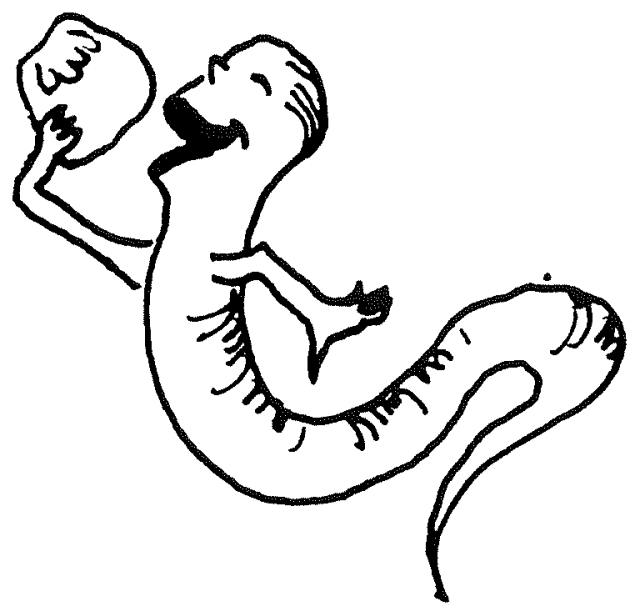

\section{Questions}

1. If your pig weighs 50 lbs. how much protein should his feed have?

2. What level protein should a finisher ration have?

3. If your pig weighs $100 \mathrm{lbs}$. how much (about) should he be gaining every day?

4. How many weeks will you have your pig if you buy him when he weighs 40 lbs. and show him when he weighs 220 lbs. Hint: there are 7 days in the week.

5. Name two diseases pigs can get.

6. When should a pig be dewormed? 


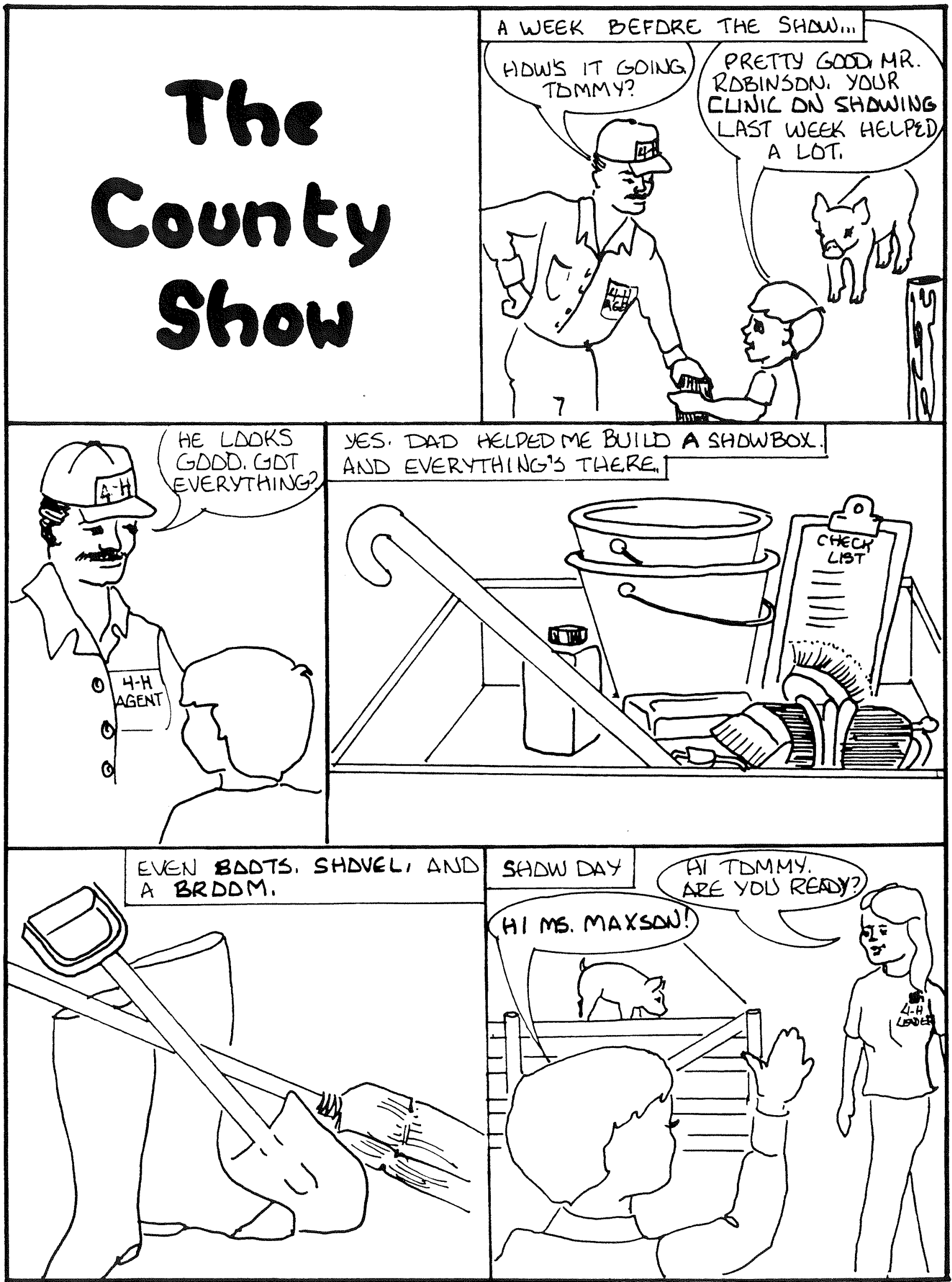




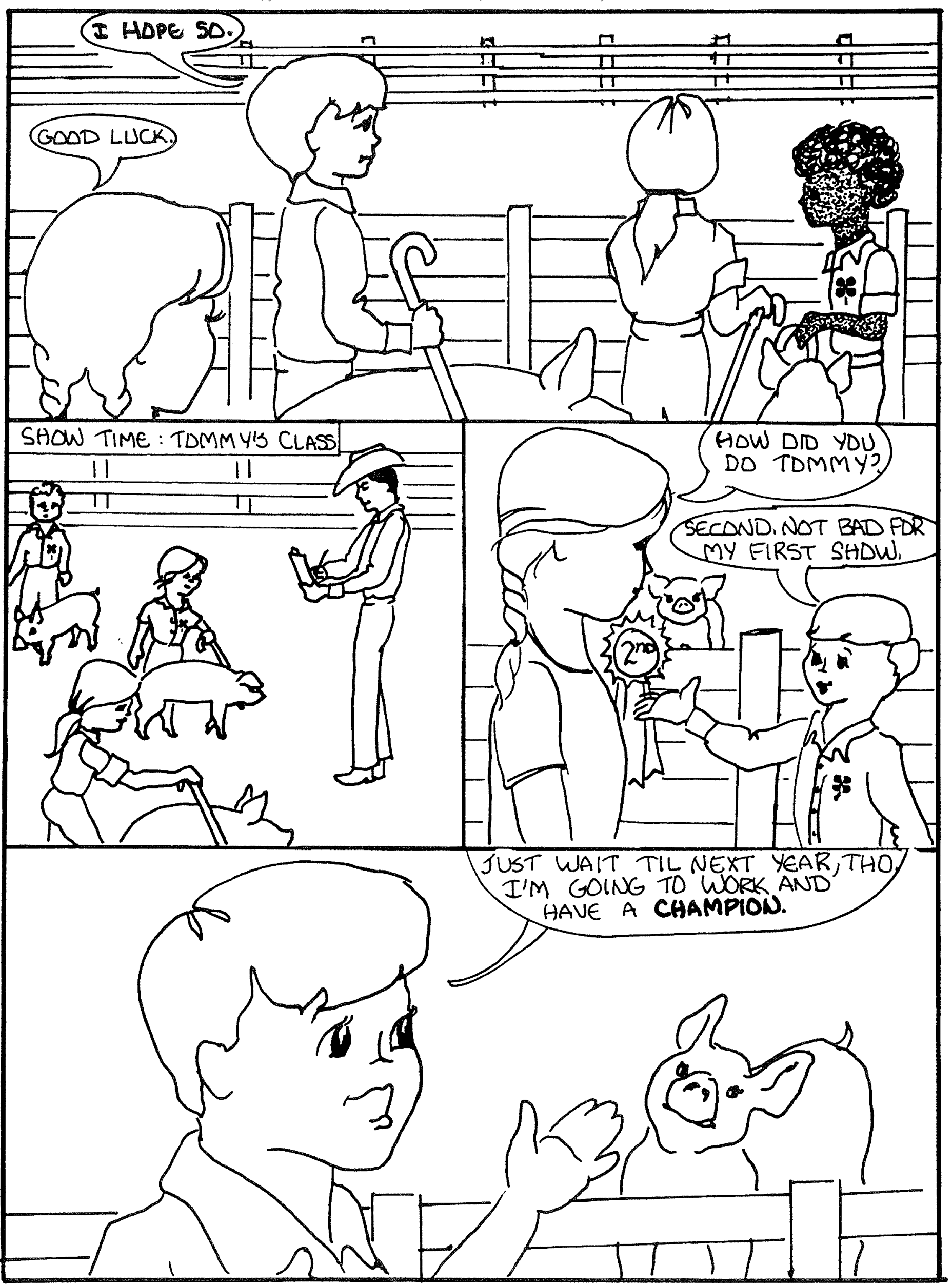




\section{SHOWING YOUR PROJECT PIG}

\section{Start Early}

Begin training your pig well ahead of the show, using these cues:

\section{Never:}

1. Hit it on the ham.

2. Put your hand on its back.

3. Move too fast

4. Abuse your pig
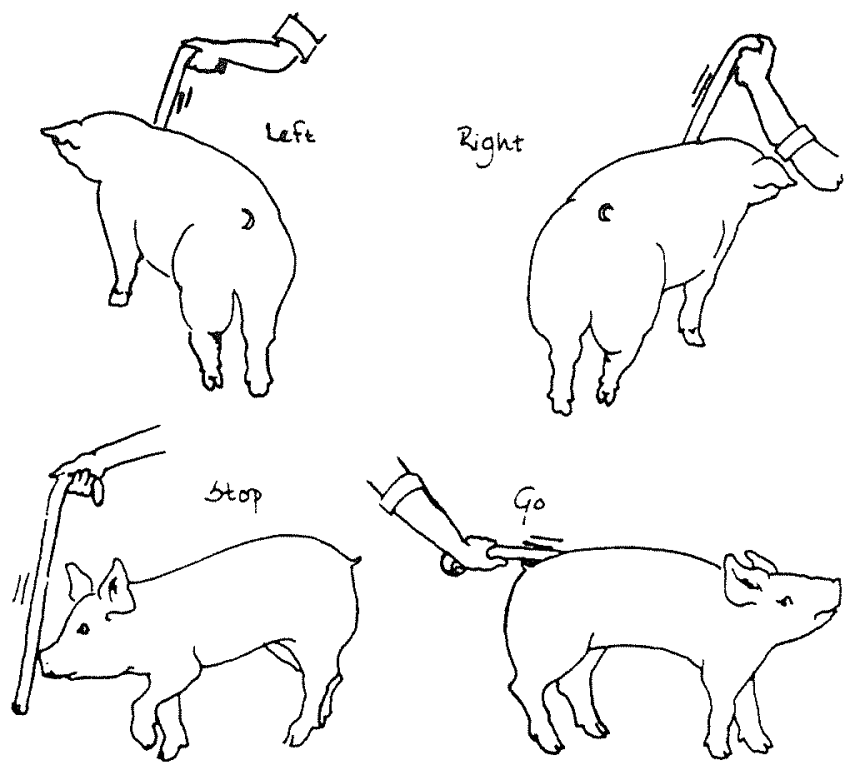

\section{Equipment Checklist}

Show box

Water bucket

Small feed trough or bucket

Bedding if not provided

Your own feed (enough to last the show)

Soap and brushes

Shovel and broom

Work clothes and boots

Show clothes

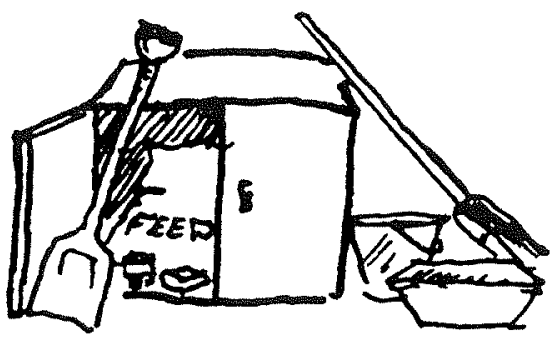

Start giving your pig baths a month ahead and brush the hair down and back to train it.

Trim his feet two weeks in advance, if necessary. Obtain show equipment at about the same time.

Clip the hair on the tail from the base to the switch a week before the show. Clip the long hair from around the ears and jowl, and on the belly. Read the rules and regulations for shows.

Restudy the show procedures the night before the show.

\section{On Show Day}

Keep the pen and area and yourself clean and neat. You are on show the whole time, not just in the ring.

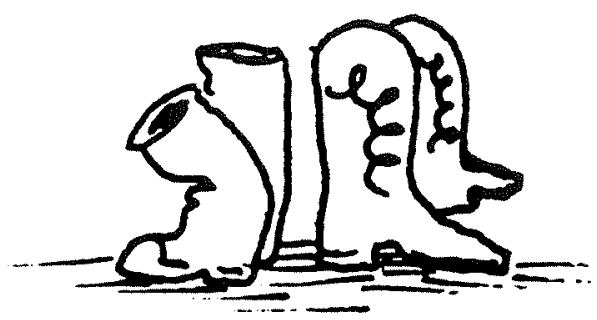

Wash your pig several hours before to allow it to dry. Brush well and rub a little talcum powder in if your pig is white. Use a very light cover of oil if your pig is a dark color. Exercise your pig a couple of hours before your class. Do not feed, just give a little water before the class.

\section{In the Ring}

\section{DO}

Present a professional appearance Keep moving slowly, but stop if asked Watch the judge at all times

Keep working until the class is over Be courteous Be a good sportsman

\section{DON'T}

Crowd the judge

Show off

Brush your pig while it is moving

\section{Activity for You}

Build and equip a show box. 


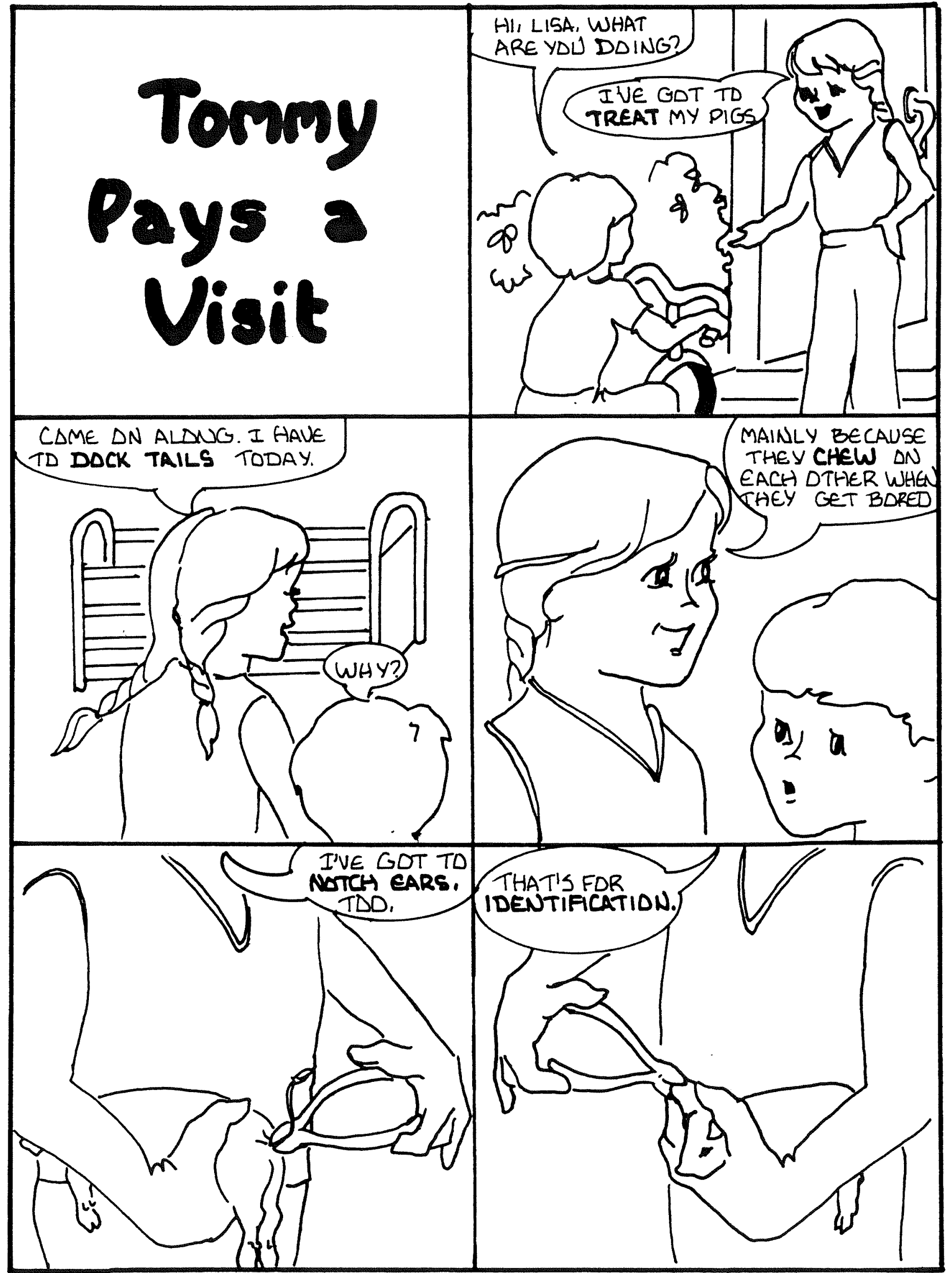




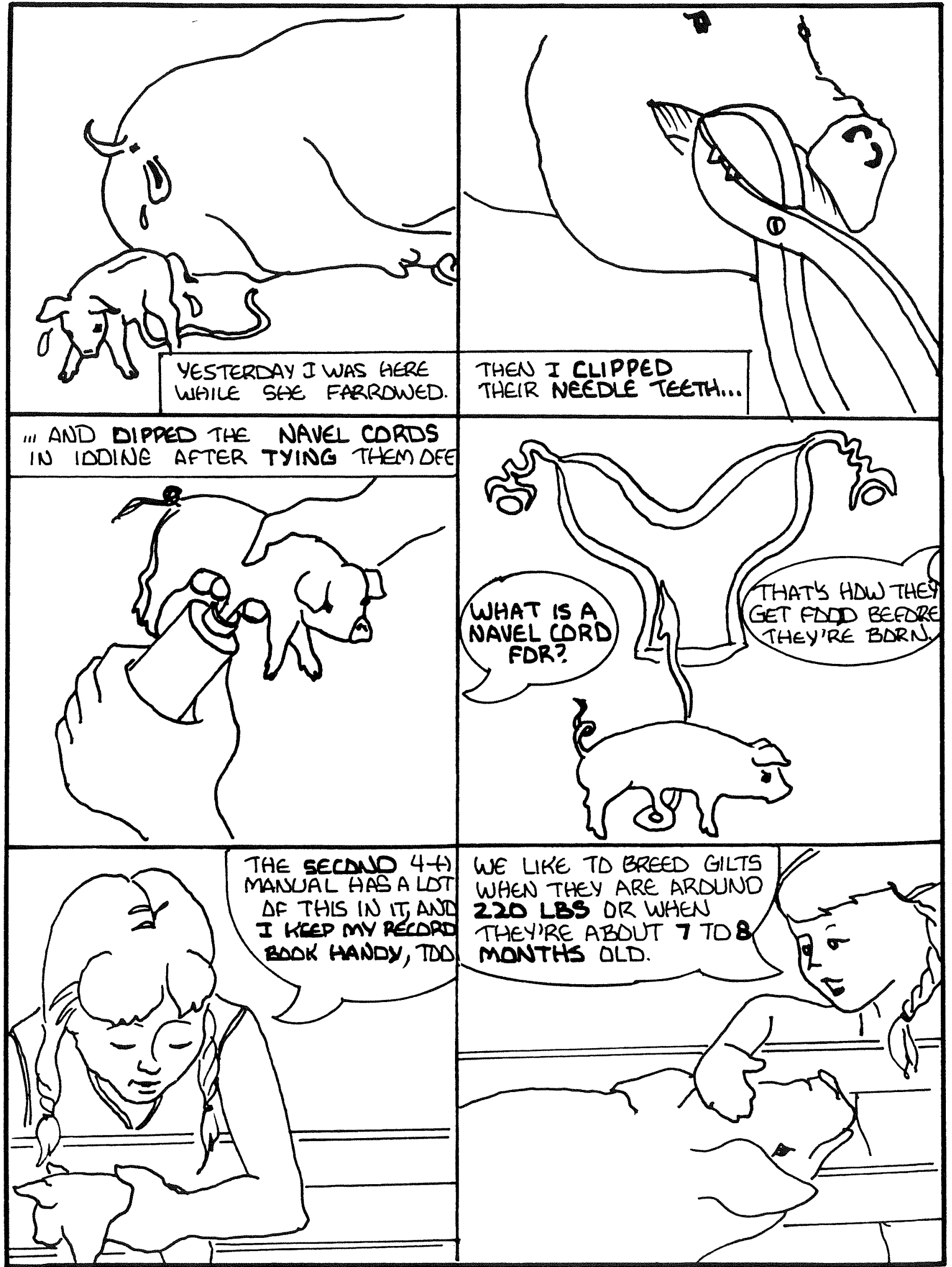




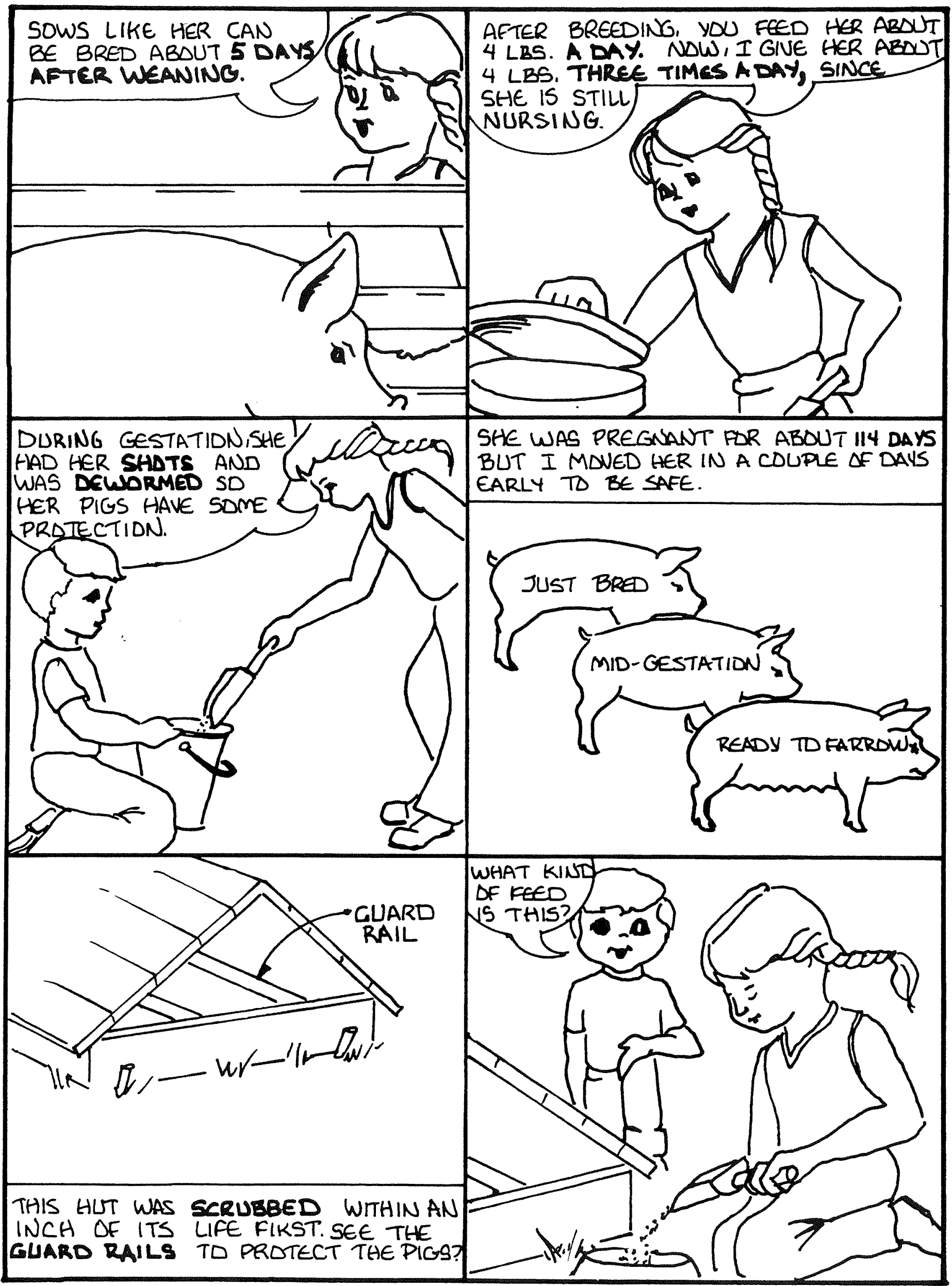




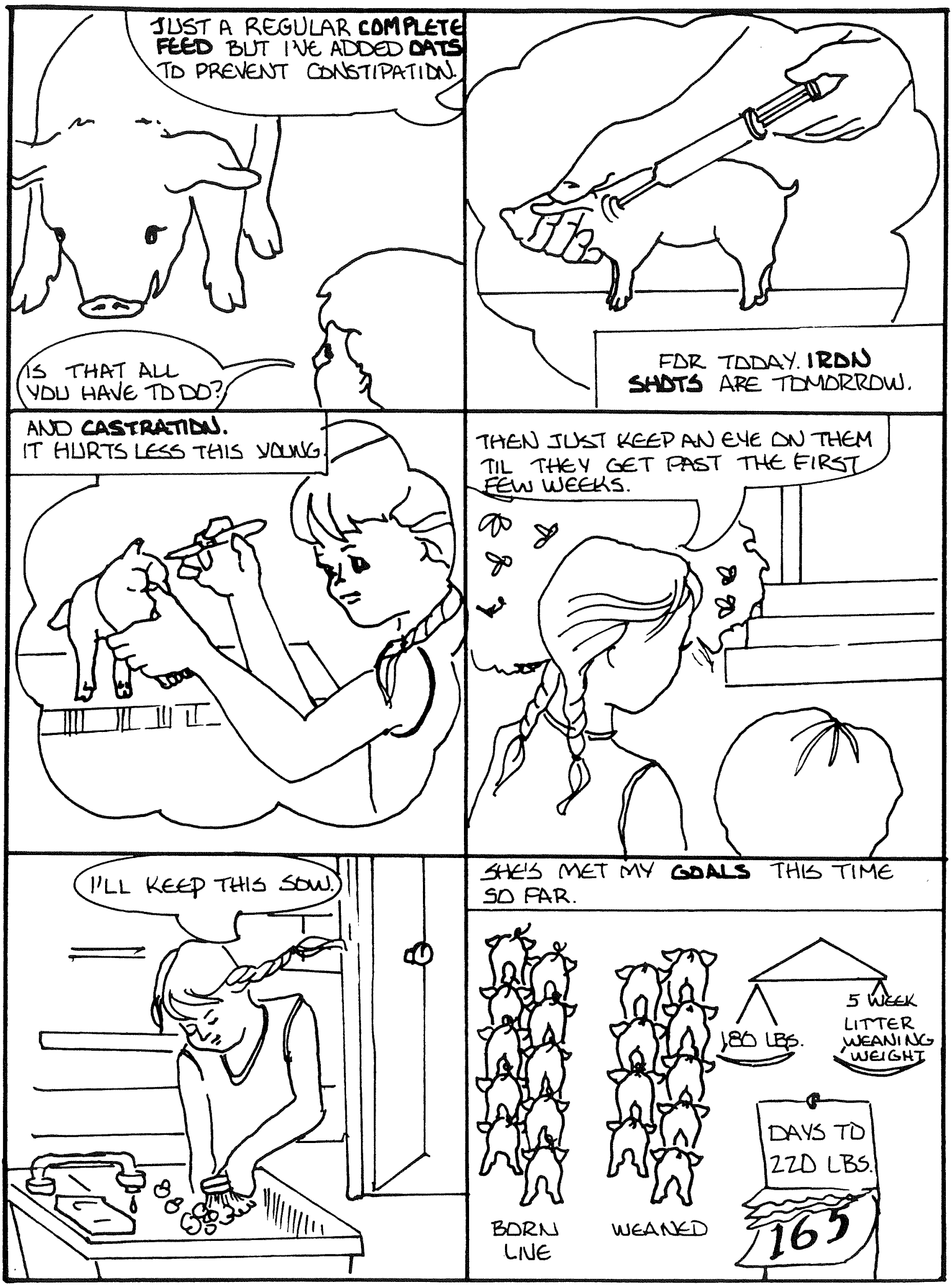




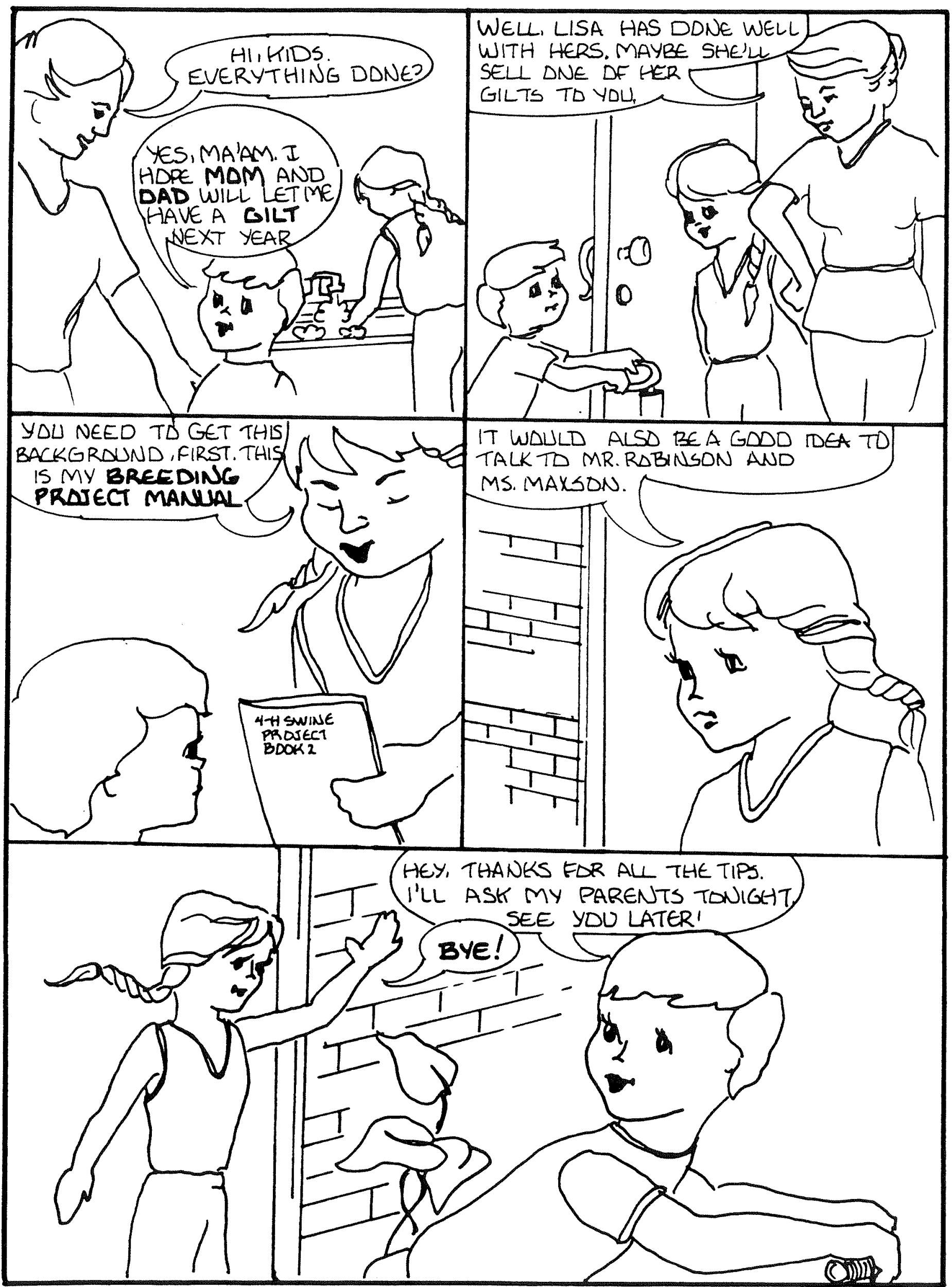


Answers to Most Often Asked Questions

Q. What weight pig should I purchase for showing?

A. Determine number of days until show time and use following guide (approximated).

\begin{tabular}{cccc}
$\begin{array}{c}\text { Pig's Wt. } \\
\text { Ibs. }\end{array}$ & $\begin{array}{c}\text { Days regrd. } \\
\text { to 220 lbs. }\end{array}$ & $\begin{array}{c}\text { Pig's Wt. } \\
\text { lbs. }\end{array}$ & $\begin{array}{c}\text { Days reqrd. } \\
\text { to 220 lbs. }\end{array}$ \\
\cline { 2 - 3 } & 140 & 60 & 103 \\
40 & 125 & 70 & 94 \\
50 & 113 & 80 & 85
\end{tabular}

Q. How much does a project pig cost?

A. Prices are dependent upon supply and demand of feeder pigs. Following is a guide for purchase of project pigs for consideration by purchaser and seller.

\begin{tabular}{cc} 
Pig Weight $X$ No. 1 Mkt. Price \\
\hline 30 lbs. & 2.2 \\
40 lbs. & 1.8 \\
50 lbs. & 1.5
\end{tabular}

\begin{tabular}{cc} 
Pig Weight $X$ No. 1 Mkt. Price \\
\hline 60 lbs. & 1.4 \\
70 lbs. & 1.3 \\
80 lbs. & 1.2
\end{tabular}

EXAMPLE: 30 lbs. $\times 2.2 \times \$ 0.40 / \mathrm{lb}$. for No. 1 market hog $=\$ 26.40$

Q. How much should I feed my pig? How much should it gain?
A.

$\frac{\text { Pig Weight }}{40-120 \text { lbs. }}$
$\frac{\text { lbs./Day }}{2.5-5.5}$
$\frac{\text { Rate of gain }}{1.4 \mathrm{lbs} . / \text { day }}$
120-220 Ibs
$5.6-8.0$
1.7 Ibs./day

Q. What level of protein should I feed?

\begin{aligned} A. Pig Weight & Protein \\ \cline { 2 - 2 } $25-60$ lbs. & $18 \% \\ 60-120$ lbs. & $16 \% \\ 120-220$ lbs. & $14 \%\end{aligned}$

Q. When should pigs be dewormed?

A. One week after arrival at your place and again at $120 \mathrm{lbs}$.

Q. What should I use to deworm pigs?

A. Atgard and Tramisol in rotation; and if threadworms (Strongoloides) are a problem, use Thiabendzole.

Additional reference: Circular \#470, Swine Production on a Small Scale, Page 7, Table 1.

Q. What should I use for external parasite control (lice and mange mites)?

A. A solution with Lindane which can be used up to 30 days prior to show or marketing, and Malathion which has no withdrawal requirement.

Q. What is the Modified Danish System of Livestock judging?

A. This system, which is used in the majority of youth shows, is a measurement for quality of animals based on three divisions - Blue ribbon for superior animal meeting accepted type, condition, or finish desired and grades a No. 1 market hog; Red ribbon for a good animal but one that lacks proper type, condition or finish desired for designated purpose and grades a No. 2 market hog; and White ribbon for an animal either poor in type, condition or finish (or has other handicaps) and grades a No. 3 market hog.

In youth shows using this system, blue grade animals in each class may be placed numerically or a first and second only. Following placing of various classes (example: market hogs, three different weight divisions), the first place blue ribbon animals for each division are eligible to compete for Grand Champion. Only blue ribbon animals are eligible to compete for Grand Champion or Reserve. Whichever class the champion comes from, the second blue ribbon pig in that class is eligible to compete for reserve. The management of each show determines the system of judging. 


\section{TALKING HOGS}

A frame-Hut shaped like an A, used by a sow and her litter on pasture.

Backfat-Amount of fat over a pig's back. It is used in selection of breeding stock.

Balanced ration - Feed that has all the things an animal needs to stay healthy and grow right.

Barrow-A castrated male pig.

Boar-Male hog

Breed-Animals that look alike and pass their looks on to their offspring.

Castrate-To make a male sterile by surgery.

Crossbreed-Animal whose parents were of dif. ferent breeds.

Crude Protein (C.P.)-Chemically analyzed protein in a given feed.

Dam-Mother

Farrow-To give birth to baby pigs.

Feed efficiency-The amount of feed a pig eats to gain one pound; the smaller the amount, the more efficient.

Feed out-To feed a pig until it reaches market weight
Feeder pig-Young weaned pig weighing between 30 and $90 \mathrm{lbs}$.

Full feed-Allowing pigs to eat as much as they want.

Gestation-Time between breeding and farrowing, about 114 days in swine.

Gilt-Young female that has not had any pigs.

Lbs.-Abbreviation for pounds. \# may also be used.

Limit feeding-Supplying a certain amount of feed only.

Needle teeth-(wolf teeth) Eight sharp teeth pres. ent when a pig is born.

Purebred-Both parents are of the same breed and are registered in the breed association registry.

Sire-Father

Sow-Female that has had one litter at least.

Vaccinate-Give shots to protect against disease.

Wean-To take pigs away from their mother.

Prepared by Kenneth L. Durrance, Extension Swine Specialist, and Cynthia A. Maxson

Art by Ruth M. Franczek

\section{REFERENCES}

American Berkshire Association

$601 \mathrm{~W}$. Monroe St.

Springfield. 111. 62704

Chester White Swine Record Association

Box 228

Rochester. In. 46975

United Duroc Swine Registry

$1803 \mathrm{~W}$. Detweiller Dr.

Peoria, III. 61614

Hampshire Swine Registry

1111 Main St.

Peoria. III. 61606

American Landrace Association, Inc.

Box 111

Culver. In. 46511

Poland China Record Association

501 E. Losey St.

Gailesburg III. 61401
National Spotted Swine Record, Inc.

$110 \mathrm{~W}$. Main St.

Bainbridge, In. 46105

American Yorkshire Club, Inc.

P. O. Box 878

Lafayette, In. 47902

Tamworth Swine Association

6580 Millers Chapel Rd.

Hillsboro, Ohio 45133

Recognition is due the following schools for materials used as guidelines for this manual: Colorado State University ( $\mathrm{Col}$ orado 4.H Swine Enterprise); Texas A \& M University (4.H Swine Manual): University of Tennessee (4-H Swine Handbook): and University of Wisconsin (Pork Production: Project Guide for Members and Leaders). Many thanks to the breed associations who supplied the photographs used in the chapter Getting to Know Pigs. 
1. This document is 4HSWM10 of the Florida 4-H Youth Development Program, Florida Cooperative Extension Service, Institute of Food and Agricultural Sciences, University of Florida. Printed; December, 1990, Reviewed June 2002. Please visit the EDIS website at http://edis.ifas.ufl.edu.

2. Kenneth L. Durrance and Cynthia A. Maxson. Publication contact: Nancy Johnson, 4-H Publication Coordinator, Department of Family, Youth and Community Sciences, Cooperative Extension Service, Institute of Food and Agricultural Sciences, University of Florida, Gainesville 32611.

COOPERATIVE EXTENSION SERVICE, UNIVERSITY OF FLORIDA, INSTITUTE OF FOOD AND AGRICULTURAL SCIENCES, Christine Taylor Waddill, Director, in cooperation with the United States Department of Agriculture, publishes this information to further the purpose of the May 8 and June 30,1914 Acts of Congress; and is authorized to provide research, educational information and other services only to individuals and institutions that function without regard to race, color, age, sex, handicap or national origin. The information in this publication is available in alternate formats. Single copies of extension publications (excluding 4- $\mathrm{H}$ and youth publications) are available free to Florida residents from county extension offices. Information on copies for out-of-state purchase is available from Publications Distribution Center, University of Florida, PO Box 110011, Gainesville, FL 32611-0011. 